\title{
Knowledge based capital and value creation in global supply chains
}

\author{
Cecilia Jona-Lasinio $^{\mathrm{a}}$, Stefano Manzocchi ${ }^{\mathrm{b}, 1}$, Valentina Meliciani ${ }^{\mathrm{c}, 1_{\text {,* }}}$ \\ a ISTAT and Luiss Lab of European Economics, Italy \\ ${ }^{\mathrm{b}}$ Department of Economics and Finance, LUISS University, Italy \\ ${ }^{c}$ Department of Business and Management, LUISS University, Italy
}

\section{A R T I C LE IN FO}

Accepted by: Dirk Meissner

Keywords

Knowledge-based capital

Global value chains

Forward and backward participation

Value added appropriation

\begin{abstract}
A B S T R A C T
This paper investigates the role of knowledge-based capital for participation and value appropriation in global value chains (GVC) for a sample of European countries over 1995-2011. We distinguish between different forms of participation in GVC entailing a different degree of capability to create value added domestically and examine how different intangible assets contribute to countries' engagement and value appropriation in GVC. We find that knowledge-based capital is positively correlated with participation and value appropriation along the value chain. This finding is robust to introducing separately R\&D and non-R\&D intangibles. In particular, training and organizational capital have the largest positive effect on value appropriation [JEL Classification: F23, O30].
\end{abstract}

\section{Introduction}

The structural and technological changes associated with the rapid progress in Information and Communication Technologies (ICT) have led to widespread processes of globalisation of value chains over the past two decades (for recent reviews, see Kaplinsky, 2016; De Backer and Miroudot, 2013; Timmer et al., 2014). Baldwin (2011) has defined these as a 'second unbundling' of globalisation, which has transformed the terms of international competition and shifted the barycentre of the world's global headquarters and peripheries.

At the same time, the changing nature of the global economy, the rising role of the service sector and the emergence of new business models have placed a novel attention on intangible capital or knowledge-based capital as a key element of global competition and growth (Corrado et al., 2005, 2009).

However, the literature on the determinants of GVC participation (Cheng et al., 2015; Hummels and Schaur, 2013 ; Kowalski et al., 2015; López-Gonzalez et al., 2015; WTO, 2014) and gains from participation (Dedrick et al., 2010; Gereffi et al., 2005; Kaplinsky, 2000; OECD, 2013b; Shin et al., 2009, 2012) and the studies on the macroeconomic effects of investments in intangible assets (Corrado et al., 2005, 2009, 2013, 2016, 2017; Fukao et al., 2009; Hao et al.,
2008; Jalava et al., 2007; Marrano et al., 2009) have remained two distinct fields of analyses, so far.

The purpose of this paper is to bridge these two research fields by investigating the linkages between the accumulation of intangible capital and both GVC participation and value appropriation at the country-industry level. We formulate and empirically test four hypotheses on the interrelationships between intangible assets and modes of country-industry participation in GVC. Our assumptions are grounded on the firm level literature on the functions of intangible assets as source of value along the chain (Dedrick et al., 2010; Mudambi, 2007; Shin et al., 2009,2012 ) and generalized to the country-industry dimension.

We think we contribute to the literature providing a new perspective on the relevance of knowledge-based capital for GVC participation and value appropriation, showing that: 1) there is a direct effect of intangible capital on GVC participation; 2) the impact of intangibles on participation differs depending on modes of participation (forward and backward) and type of industry (manufacturing and in services); 3) intangible assets contribute to value appropriation from participation in GVC.

The analysis exploits disaggregated data on different intangible assets (R\&D, marketing and advertising, design, training, organizational capital) from the INTAN-Invest database $^{2}$ to ex-

\footnotetext{
* Corresponding author.

Email addresses: cjonalasinio@luiss.it (C. Jona-Lasinio); smanzocchi@luiss.it (S. Manzocchi); vmeliciani@luiss.it (V. Meliciani)

1 LUISS University.
} 
plore their (possibly) differentiated function in favouring GVC participation and value appropriation. The data cover 11 European economies, over the period 1995-2011distinguishing between manufacturing and total market services. Data on intangibles are then merged with different measures of participation in global value chains gathered from OECD-WTO Trade in Value Added (TiVA) database.

The paper is structured as follows. Section 2 provides an overview of the relevant literature and illustrates our research hypotheses. Section 3 offers some descriptive evidence on the extent of countries' participation in GVC and on its correlation with intangible investment. Section 4 presents the empirical strategy. Section 5 discusses the econometric results and Section 6 concludes.

\section{Knowledge-based capital and participation in global value chains: background literature and research hypotheses}

The empirical literature on growth and international competitiveness has shown since long ago that competitive advantage, at both the country and firm level, is based on the ability to accumulate distinctive sets of capabilities and competencies and to assimilate knowledge more than on price-cost factors (Cohen, 2010; Dosi et al., 1988, 1990, 2015; Fagerberg, 1994; Laursen and Meliciani, 2010; Maggi, 2017).

More recently, a new element has emerged as an important driver of innovation, growth and competitiveness in the advanced economies: intangible or knowledge-based capital, broadly defined to include computerized databases, R\&D, design, brand equity, firm-specific training, organizational efficiency (e.g., see Corrado et al., 2005, 2009, 2017). At the same time, the structural and technological changes associated with the rapid progress in Information and Communication Technologies (ICT), the rising role of the service sector and the development of new business models make intangible investments a key element of global competition in the 'knowledge-based economy'.

Existing empirical evidence shows that investments in intangible assets are expanding rapidly (e.g. in the United States, Japan and also in some European countries) outpacing investment in traditional assets (machinery and equipment, buildings, etc.) and impacting significantly on productivity growth both directly (Marrano et al., 2009; Jalava et al., 2007; Fukao et al., 2009; Hao et al., 2008; Corrado et al., $2013)^{3}$ and by generating knowledge spillovers to the economic system (Corrado et al., 2017).

While there is a growing literature looking at the relationship between investment in intangible assets and productivity growth, the only study relating one specific intangible asset (organizational capital) and backward GVC participation is Marcolin et al. (2017). They find that industry-level investment in organizational capital is causally linked to GVC in the form of backward linkages with the foreign market.

The current literature exploring the functions of intangible assets along the value chain has shown that a great part of the value added of a final product is created in the first and last stages of the production process by firms involved in $R \& D$, de-

\footnotetext{
2 INTAN-Invest (www.intaninvest.net) is an unfunded research initiative that periodically provides intangible investment estimates for $27 \mathrm{EU}$ countries, the United States, and Norway see www.intan-invest.net for further details. The forthcoming INTAN-Invest update is reviewed and analyzed in Corrado et al. (2016).

3 For a review of the literature see Thum-Thysen et al. (2017).
}

sign, marketing and advertising, while firms involved in intermediate stages (such as the production of components and assembly) reap only a small part of the final value of the good or service produced (Dedrick et al., 2010; Mudambi, 2007, 2008; Shin et al., 2009, 2012). The pattern of value-added along the value chain may, therefore, be represented by the 'smiling curve' (Everatt et al., 1999) or the 'smile of value creation' (Mudambi, 2007): ranking activities on the x-axis along the value chain (activities at the left or 'input' end are supported by R\&D knowledge while activities at the right or 'output' end are supported by marketing knowledge), value added will be higher in the first and last stages of the value chain. ${ }^{4}$

Hence the literature at the firm level has provided insightful hints on the relationship between intangibles and value creation in GVCs, but the link between knowledge-based capital and the extent of participation of firms and countries in GVCs has been overlooked.

Taking a business perspective, Corrado and Hao (2014) show that overall intangible assets provide, relatively to tangibles, a larger contribution to value creation both in pre-production (R\&D, design) and post-production (marketing, services) stages. In this paper, we link the firm and the business perspectives on intangibles in the value chain to formulate and test hypotheses on the conditional effect of the endowment of intangible capital at the country/industry level on participation and value appropriation in global value chains.

It is important to point out that the notion of a value chain is defined at the product level while at the economy-wide level the concept is more obscure since firms' value chains intersect and overlap (Baldwin, 2012). However, data on the international fragmentation of production are only available at the industry/country level. These data allow to track the origin of value added, by country and sector, which is embodied in gross exports (Koopman et al., 2010, 2014). Using these data we can proxy country participation and value appropriation in GVCs at the industry level.

Participation of countries in a GVC at the industry level captures the total involvement of a country in the various production stages (both as a buyer and as a seller of intermediates) leading to final exports (domestic and foreign) of that industry and it includes both the domestic value added in foreign exports and the foreign value added in domestic exports. Countries' participation, therefore, differs from countries' value creation, i.e. the capability of the firms of that country to generate value added at different production stages of the global value chain. Finally, value appropriation refers to the portion of the value added created in the industry and retained by the country.

In order to formulate hypotheses on the role of intangible assets for countries' participation and value appropriation in GVCs, we discuss the macroeconomic implications of studies carried out at the firm level. Firms participating in GVCs combine the comparative advantages of geographic locations with their own resources and competencies to maximize their com-

\footnotetext{
4 Rungi and Del Prete (2017), using data for more than two million of firms in the European Union, detect a non-linear U-shaped relationship between the value added generated by firms and their position on a productive sequence, for which tasks at the top and at the bottom show higher value added. They also find empirical support for a phenomenon of domestic retention of value added by multinational enterprises, which may prefer keeping at home the tasks at higher potential to safeguard present and future competitive advantages.
} 
petitive advantage (McCann and Mudambi, 2005). In the classical example of Apple's iPod, Apple keeps most of its product design, software development, product management, marketing and other high-wage functions in the U.S., while Asian firms like Toshiba from Japan and Samsung from South Korea manufacture high value components and firms from China are mainly specialized in assembling and testing activities (Dedrick et al., 2010). Timmer et al. (2014) argue that the patterns of specialization identified in case studies like the iPod have a macroeconomic equivalent. They show that firms in mature economies relocate their unskilled labor-intensive production activities to lower-wage countries, while keeping strategic and high-value-added functions concentrated at home where the skilled workers and intangible capital they need are available. ${ }^{5}$ Countries that invest more in knowledge-based capital can be attractive locations for high value added activities due to localized knowledge spillovers. In fact, although the participation of firms in GVCs may reflect their ownership-specific advantages, knowledge capital internal to the firm and intangible assets available in the economy are complementary assets for firms' performance. At the macro/regional level, the effects of intangible capital endowments on the performance of both firms and the local economy are usually interpreted as localized externalities which influence positively the agglomeration of the production activities (Marrocu et al., 2012). Spillovers and complementarities between public and private R\&D and between education and employer provided training (O'Mahony, 2012) generate positive feedback mechanisms affecting the location of intangible-intensive functions in the GVC. ${ }^{6}$ The OECD also finds that countries that invest more in knowledge-based capital are the countries that reallocate resources to innovative firms more effectively (OECD, 2013b).

Intangibles are also strategic in the coordination of global value chains. International fragmentation of production requires the coordination of the various stages of production which are spatially dispersed To realize the matching of production teams and ideas, GVC integration requires managerial capabilities and a dense circulation of information flows to communicate specifications, standards, technical know-how in addition to costs and other items (Gereffi et al., 2005). The efficient organization of production in GVCs is thus mostly based on investments in intangible assets (Durand and Miller, 2018).

On this ground we formulate our first testable hypothesis:

HP1Participation in global value chains increases with investment in intangible assets.

The studies on the industry dimension in GVC have mainly focused on manufacturing so far. However, an emerging literature highlights the growing service content of exports and GVC (Gereffi and Fernandez-Stark, 2010; OECD, 2013b; Kommerskollegium, 2012; Lanz and Maurer, 2015) emphasizing

\footnotetext{
5 In an extended Heckscher-Ohlin framework, Haskel et al. (2012) assume that skilled workers are more productive in tasks involving working with intangible capital and show how this might explain the evolution of relative wages in the United States.

6 One limitation is that the GVCs are characterized by the fact that the business functions are carried out in different parts of the world thus making the identification of the statistical unit carrying out the activity more complex than it is currently in National Accounts. This is why United Nations are working to build a satellite account able to represent the production boundaries in a GVC (UNSD, 2018). The availability of this information will allow a more accurate identification of the location of intangible assets to be used in future studies.
}

the relevance of exploring possible sectoral differences of factors affecting GVC participation (López-Gonzalez et al., 2015).

Previous studies have shown that innovation can play an important role for international competitiveness in services (Guerrieri and Meliciani, 2005). However, the more traditional technological variables, such as R\&D expenditures, might not be the most relevant ones for explaining competitiveness in service industries. In fact, innovation indicators such as R\&D and patents were developed for manufacturing with a focus on technological innovation. These indicators insufficiently capture service innovation activities which are strongly related to competencies and knowledge and are generally less formalized (i.e. they are mostly not based on formal R\&D, but on the interaction with users, with a high importance of knowledge, skills and creativity, see e.g. Schricke et al., 2012). Actually, although manufacturing sectors spend more on R\&D than service sectors, when the definition of innovation is broadened to include marketing, training and other innovative activities, many services have much higher spending than manufacturing (Tomlinson, 2000). The intangible and information-based nature of services makes the generation and use of ICT playing a central role in firms' innovation activities and performance (Evangelista, 2000). The same role can also be played by other intangible assets different from R\&D such as training and branding. ${ }^{7}$ Referring to this evidence we formulate our second hypothesis:

HP2Each intangible asset can exert a different impact on GVC participation in manufacturing and service industries. R\&D is likely to have a larger effect in manufacturing than services while ICT and other non-R\&D intangibles are expected to be equally important in both sectors.

The empirical literature on GVC participation (Koopman et al., 2010, 2014; Los et al., 2015; Timmer et al., 2013) identified two modes of GVC participation: forward and backward. Forward participation is captured by domestic value added embodied in foreign exports (or in foreign final demand) while backward participation by foreign value added embodied in domestic exports (or in domestic final demand). Further, the relative importance of backward and forward linkages may signal the position of a country in the value chain of a given sector. If a country lies upstream in the global value chain, it participates by producing inputs for others, and its forward linkages will be higher than its backward linkages. On the other hand, if a country lies downstream in the global value chain, it will use a large portion of other countries' intermediates to produce final goods for exports, and its backward linkages will be higher than its forward linkages (Koopman et al., 2010).

The relative importance of backward and forward linkages also depends on the size of the country and on the type of production activity. Natural resource-rich countries and headquarter economies tend to have higher domestic value added in their exports, while smaller countries and factory economies tend to exhibit lower domestic value added in their exports (Kowalski et al., 2015; ).

Intangible capital might therefore exert a different function depending on the innovative characteristics of each asset (prod-

\footnotetext{
7 Niebel and O'Mahony (2017) find that the contribution of intangible investment to productivity growth in European countries is generally highest in manufacturing and finance but the data also show a high contribution in business services in several countries, most notably in the Netherlands and the UK. Marrocu et al. (2012) find that for service activities the marginal contribution to output formation of the intangible capital is higher than that of the tangible one.
} 
uct or process innovation) and on mode of participation. Ideally, R\&D and design, lie upstream in a production sequence, while marketing and advertising are located relatively more downstream. R\&D and design can be strategic assets for the production of both final and intermediate goods and services, so that they can contribute to both backward and forward participation. On the other hand, due to the higher degree of information asymmetries between buyers and sellers, marketing and advertising are likely to be more important for final products and, therefore, to backward participation. Other assets such as training and organizational capital can be viewed as widespread business functions in a GVC as they are possibly contributing to all production stages. More specifically, some intangible assets may contribute more to organizational innovation (organizational capital) others to product innovation (brand, design) while others can have a more widespread impact (R\&D, training). Thus, we cannot assume that each intangible asset univocally contributes only to one mode of participation. Moreover, intangibles appear to be complementary, both with technological assets, such as ICT (see Corrado et al., 2017) and among them as R\&D and marketing: firms that innovate along the R\&D margins are also likely to be innovative and/or effective in marketing (Corrado and Hao, 2014).

We, therefore, formulate our third hypothesis:

HP3All intangible assets are likely to positively affect both forward and backward participation although marketing and advertising are expected to exert a stronger impact on backward linkages.

Participation in GVC can be important in itself by allowing countries at different stages of development to exploit foreign demand and specialize in tasks along the value chain rather than having to set up entire processes of production from scratch (see also Baldwin and López-Gonzalez, 2015; OECD, 2013b), however not all forms of participation generate comparable returns (Gereffi et al., 2005; Kaplinsky, 2000; Schmitz and Strambach, 2009).

The main argument of this paper is that intangibles are critical assets both to foster GVC participation and to increase the capabilities to benefit from a higher share of value added created along the chain. Cheng et al. (2015) find that countries with greater economic complexity (pertaining to the number of distinct products that a country makes) have tended to capture a larger share of the value added from GVCs than those with lower economic complexity. The positive impact of intangible assets (Corrado et al., 2005, 2017) and of managerial practices (Bloom et al., 2016; Bloom and Van Reenen, 2007) on firms' and counties' total factor productivity indirectly suggests that intangible assets, including organizational capital, may increase complexity and contribute to value added appropriation along the supply chain.

Mudambi (2018) observes that the returns to intangible assets can appear in the form of legally defensible rents as in the case of patents, copyrights and brands (Lev, 2001), but also in the form of superior returns generated by inimitable organizational structures and inter-organizational relationships (Augier and Teece, 2006; Grant, 1996; Kogut and Zander, In all cases, the firm controlling an intangible asset is able to generate higher returns, ceteris paribus, than a competing firm that does not control the asset (Mudambi, 2008).Durand and Miller, 2018

Gereffi et al. (2005) identify different types of global value chain governance (hierarchy, captive, relational, modular, and market) which range from high to low levels of explicit coordination and power asymmetry. The key insight is that coordination and control of global-scale production systems, despite their complexity, can be achieved without direct ownership. In captive value chains there is a high degree of explicit coordination and a large measure of power asymmetry with the lead firm (or top management) being the dominant party. This control requires high managerial capabilities on the side of the leading firm as in the case of hierarchies. In order to achieve a more balanced power between the firms in the GVC, suppliers need to develop specific capabilities as in relational and modular value chains. The management of intangible assets is crucial for enhancing firms' dynamic capabilities (Schiller and Perera, 2012).

Intangibles may affect value appropriation along a GVC also due to uneven returns to scale on intangibles with respect to tangibles. Durand and Miller, 2018claim that intangible assets such as standards, specifications, R\&D achievements, as well as software and organizational know-how are typically scalable assets, imposing negligible marginal costs following the initial investment made to create them and resulting in infinite returns to scale. The difference in scale economies between tangible and intangible assets implies that the firms controlling intangible-intensive parts of the chain will receive a disproportionate share of the gains from the network as output expands. This is why intangible capital is a key element for value appropriation along the chain.

Our assumption is that the degree of intangible intensity affects the capability of reaping the benefit of GVC participation also at the country/industry level: the distribution of intangible-intensive and non-intangible intensive firms across the world is highly skewed, thus countries/industries with a larger number of intangible-intensive firms will be in the position of reaping a relatively higher share of value added from participation in global supply chains. This leads to our fourth hypothesis:

HP4Investment in intangible assets favor value appropriation in GVC.

\section{Data and descriptive statistics}

\subsection{Measures of GVC participation}

Our measures of GVC participation are gathered from the OECD-WTO Trade in Value Added (TiVA) database. ${ }^{8}$ They track the origin of value added, by country and sector, which is embodied in gross exports. The indicators are based on the work of Koopman et al. (2010, 2014) and Timmer et al. (2013) and extend the work of Hummels et al. (2001) and Johnson and Noguera (2012). Hummels et al. (2001) compute an index of vertical specialization given by the use of imported inputs in

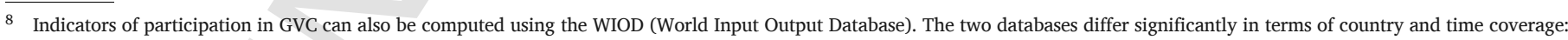

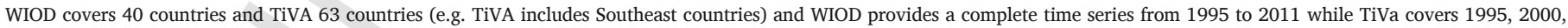

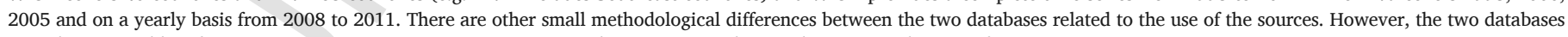
provide comparable information. In our paper, we resort to TiVA mainly since it provides "ready to use" indicators of participation in GVC.
} 
producing goods that are exported. However, this indicator does not take into account that a country exports intermediates that are used to produce final goods absorbed at home. By using input-output data for source and destination countries simultaneously, Johnson and Noguera (2012) overcome this limitation and compute the ratio of value added to gross exports as a measure of the intensity of production sharing. Finally, Koopman et al. $(2010,2014)$ provide a full decomposition of value added which includes returned domestic value added (domestic value added that comes back incorporated in foreign inputs produced with domestic inputs) and the indirect exports to third countries.

A variant of this indicator decomposes value added, similarly across countries and sectors, but according to final demand (Los et al., 2015; Timmer et al., 2013). This tracks not just the value added traded in the production of exports, but also that used to satisfy domestic and international final demand. Both indicators (that based on exports and that based on final demand) involve similar calculation techniques but the former is solely concerned with exporting activities whereas the latter considers the origin of value added in GDP. The difference is important because domestic final demand and gross export vectors differ. For our estimations, we mainly rely on the former indicator which has been more often used for measuring participation in GVC (OECD, 2013b). However, we report robustness checks with the indicator which considers total final demand thus providing a less restrictive definition of a GVC (participation in GVC includes also cases in which countries source inputs internationally and add domestic value which is consumed internally).

Both indicators (export-based and final-demand based) can be split into backward and forward participation. In particular, domestic value added embodied in foreign exports (DVAFEX) or in foreign final demand (DVAFFD) capture the domestic value added content of gross exports (or of final demand) and include the value added generated by the domestic industry during its production processes as well as any value added created from upstream domestic suppliers that is embodied in exports (or in final demand). This measure is likely to be higher for countries (and sectors) involved in upstream production, with output and exports of that country feeding into the production and exports of downstream producers (i.e. forward integration). Foreign value added content of gross exports (FVADEX) or of final demand (FVADFD) capture the value of imported intermediate goods and services that are embodied in a domestic industry's exports (or final demand). The value added can be generated from any foreign industry upstream in the production chain. It is used to measure the extent to which a country's exports (final demand) are dependent on imported content, the so-called backward integration. It is therefore likely to be higher if a country (or sector) is involved in downstream production. The sum of the two indicators is a measure of overall participation in GVC.

Finally, we measure countries' capability to appropriate a high share of value added created along the GVC. To this purpose, Banga (2013) suggests that a break-up of forward linkages and backward linkages can provide a useful insight into the value added that goes to a country from its GVC participation. In fact, the higher are the forward linkages as compared to the backward linkages, the higher is domestic value appropriation (the country is creating and exporting more domestic value-added than the foreign value added which it is import- ing). Therefore, we use the ratio of forward to backward participation as a measure of value appropriation. ${ }^{9}$

\subsection{Intangible assets}

We rely on the list of intangible assets proposed by Corrado et al. (2005) and measured by Corrado et al. (2013) combining National Accounts data on intangibles with estimates of the assets not yet incorporated in National Accounts. ${ }^{10}$

Intangible assets are classified into three broad groups - computerized information, innovative property and economic competencies. Computerized information includes computer software and databases. Innovative property refers to the innovative activity built on a scientific base of knowledge as well as to innovation and new product/process R\&D more broadly defined. Economic competencies indicate spending on strategic planning, worker training, redesigning or reconfiguring existing products in existing markets, investment to retain or gain market share and investment in brand names.

The Systems of National Accounts (2008) currently incorporates in the asset boundary only an array of intangible assets namely R\&D, mineral exploration, computer software and databases, entertainment, literary and artistic originals, under the category 'intellectual property products'. The remaining assets are treated as intermediate expenditures in official statistics. The INTAN Invest initiative ${ }^{11}$ provides harmonized estimates of intangible investments covering all asset categories proposed by Corrado et al. (2005) combining National Accounts data on intangibles with estimates of the assets not yet incorporated in National Accounts.

A relevant characteristic of the INTAN-Invest measures of intangibles is that they are consistent with National Account principles and are entirely based on official statistics. In this paper, we select from the INTAN database information for the following set of intangible assets that, together with R\&D, should capture knowledge based capital: Design, Advertising and Market research (Brand), Training and Organizational capital. $^{12}$ The main original data source to build indicators for these intangibles is Eurostat. In particular, investment in Advertising and Market Research, Design and Organizational Capital are calculated adopting an expenditure approach and resorting to expenditure data by industry from the Use Tables, compiled according to the new classification system (NACE Rev2/CPA 2008). Firm specific Human Capital (training) is computed on the basis of total training investment expenditure from the Continuing Vocational Training Survey and Labour Cost Survey. Measures of own account organizational capital are obtained from em-

\footnotetext{
9 The measure is an imperfect indicator since it is affected by the position of a country in the value chain. However, using this measure, Banga (2013) finds that, in case of US, Japan and UK, forward linkages are much stronger than backward linkages, indicating net value-added gains from linking into GVC. China and Korea, on the other hand, have negative net value added gains. This is in line with our expectations on value added appropriation.

10 For a detailed description of the methodology, see Corrado et al. (2016). These indicators have been used in many studies especially for assessing their contribution to GDP and productivity growth (see e.g. Corrado et al., 2009, 2013, 2016, 2017).

11 INTAN-invest is a research collaboration dedicated to improving the measurement and analysis of intangible assets (www.intaninvest.net).

12 The database used in this paper resorts to R\&D expenditure from BERD and not to R\&D National Account data to be coherent with the EUKLEMS (2012) figures that were not yet adjusted to the new European System of National Accounts (ESA 2010). Moreover, we do not use INTAN data on software since we include total Information and Communication Technologies (ICT) capital taken from EUKLEMS.
} 
ployment data by type of occupation and by industry (e.g. from the Structure of Earning survey or the Labour Force survey) following the cost-based approach widely adopted in national accounts. Additional information about data sources and estimation methods can be found in Corrado et al. (2013) and in the appendix of Corrado et al. (2017).

\subsection{The database}

The database employed in this paper is built merging different data sources in order to link information on intangible assets with indicators of participation in global supply chains, while at the same time controlling for other determinants of GVC participation. The main data sources include: INTAN-Invest for data on intangible capital; Trade in Value Added (TiVa) database for indicators of participation in global value chains and EU KLEMS ${ }^{13}$ for data on hours worked, tangible and ICT capital. These data are available by industry but at different levels of aggregation so to merge them it is necessary to take into account two main aggregate sectors: total manufacturing and total market services.

The empirical analysis includes also a set of control variables, at the country level, gathered from other sources (World Bank and the OECD). The choice of these variables is informed by the few studies on the determinants of participation in GVC (Cheng et al., 2015; López-Gonzalez et al., 2015; WTO, 2014). These studies find that infrastructure and human capital favor participation, while tough regulation, tariffs and other trade impediments are detrimental. Moreover, participation also depends on the size of the country (Kowalski et al., 2015).

As a proxy for human capital we include public expenditure on education (from the Panel Dataset for Cross-Country Analyses of National Systems, Growth and Development, CANA, Castellacci and Natera, 2011), while in order to capture differences in the business environment we use a synthetic indicator of product market regulation encompassing barriers to trade and investment, barriers to entrepreneurship and state control (from the OECD, for further details see Koske et al., 2015). Differences in infrastructures are captured by tangible capital while size is proxied by population (from Eurostat). We also control for the corporate income tax rate (from OECD) since this is expected to affect location decisions of multinational enterprises.

The choice of the sample (countries and time period) is constrained by the coverage of the INTAN-Invest and TiVA databases and includes 11 European countries (Austria, Belgium, Germany, Denmark, Spain, Finland, France, Italy, Netherlands, Sweden and UK) observed over the period 1995-2011. ${ }^{14}$ Of the 27 EU countries, we included only 11 countries for which data on all categories of intangibles are available and we decided to exclude the US in order to have a more homogeneous sample.

A list of all variables and their definition is reported in Appendix 1.

13 http://www.euklems.net. See O'Mahony and Timmer, 2009, for details.

14 Data from TiVa are available only for selected years (1995, 2000, 2005 and from 2008 to 2011). Population, the corporate income tax rate, product market regulation and public expenditure on education are available only at the aggregate level. Moreover, data on product market regulation are available only for the years 1998, 2003, 2008 and 2013. Values for these years are attributed to the closest years for which we have no information.

\subsection{Descriptive analysis}

We start our analysis providing an overview of the diffusion of intangible capital accumulation and the level of participation in GVC across the EU countries.

Fig. 1 shows that intangibles account for a relatively higher share of value added in services $(8.2 \%)$ than in manufacturing $(7.0 \%)$ in six out of eleven countries. Services are significantly more intangible intensive than manufacturing in UK, Netherlands, Denmark and Belgium while in Austria and Spain the two sectors show relatively comparable shares.

Participation in global value chains (standardized by hours worked) is rather heterogeneous across countries more sizable for manufacturing compared to services (Fig. 2). Nordic and Continental EU economies (with the exception of Belgium and Finland) are relatively more involved in GVC compared to the Mediterranean countries.

The main goal of our analysis is to investigate if and to what extent intangible capital accumulation is related to the degree and the benefits of country's participation in GVC. Thus, the following figures report the correlations between different measures of participation in GVC and intangible assets.

Fig. 3 shows data on per hours worked total intangible capital against participation in GVC in manufacturing and services across the sample countries. Correlation is significantly positive in both sectors suggesting a deeper analysis is warranted.

Figs. 4 and 5 show forward and backward measures of GVC participation plotted against five different types of intangibles: R\&D, Training, Marketing and Advertising, Organizational capital and Design. As expected the correlation is strong for all assets, although in the case of Training and Organizational capital it seems stronger with forward than with backward participation.

We investigate these issues below.

\section{Empirical strategy}

The descriptive evidence revealed a positive correlation between intangibles and participation in global value chains thus supporting our main assumptions. However, in order to test our hypotheses in a more structured framework, we econometrically estimate equations for GVC participation taking into account the simultaneous effect of intangibles and other control variables. In particular, our benchmark equation is as follows:

$$
\begin{aligned}
\ln \mathrm{Y}_{\mathrm{i}, \mathrm{c}, \mathrm{t}} \mathrm{GVCj}= & \alpha_{1} \operatorname{lnK}_{\mathrm{i}, \mathrm{c}, \mathrm{t}} \text { Intgs }+\alpha_{2} \operatorname{lnK}_{\mathrm{i}, \mathrm{c}, \mathrm{t}} \mathrm{ICT} \\
& +\alpha_{3} \ln \mathrm{K}_{\mathrm{i}, \mathrm{c}, \mathrm{t}} \text { Non ICT } \\
& +\alpha_{4} \ln \mathrm{X}_{\mathrm{i}, \mathrm{c}, \mathrm{t}}+\delta_{\mathrm{t}}+\gamma_{\mathrm{i}}+\varepsilon_{\mathrm{c}, \mathrm{i}, \mathrm{t}}
\end{aligned}
$$

where:c = country (11 EU member countries), i = industry (manufacturing and total market services), and $\mathrm{t}=$ time (1995, 2000, 2005, 2008-2011). Y GVCj represents different indicators of GVC participation (total, forward and backward) and value appropriation from GVC measured as the ratio between forward and backward participation. $\mathrm{K}^{\text {Intgs }}$ is intangible capital with $\mathrm{s}=$ Total Intangible Assets, R\&D, Training, Design, Brand (advertising and marketing), Organizational capital; $\mathrm{K}^{\mathrm{ICT}}$ is $\mathrm{ICT}^{15}$ capital and $\mathrm{K}^{\mathrm{Non} \text { ICT }}$ is tangible Non ICT capital stock; $\mathrm{X}$ are other controls (corporate income taxes, country size, product

15 We resort to the usual ICT definition including software, hardware and communication equipment so that software is excluded from our intangible aggregate. 
Fig. 1

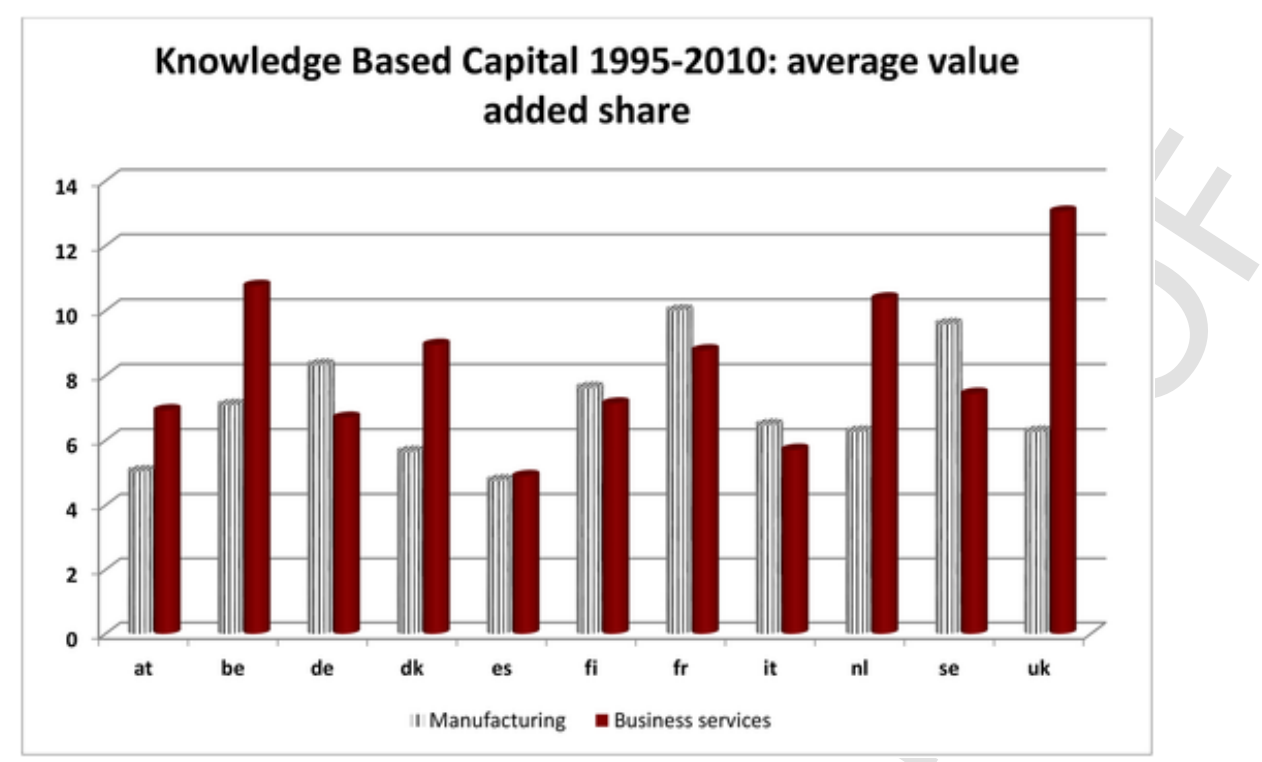

Fig. 2

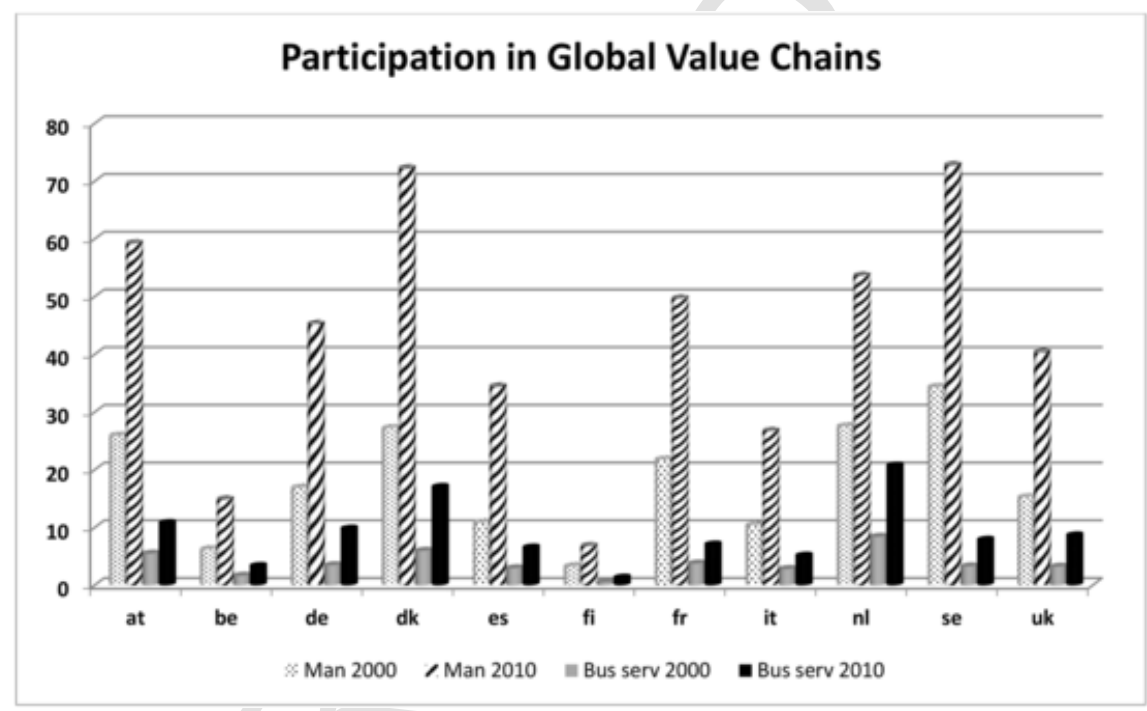

market regulation, public expenditure on education as a share of GDP); $\delta_{\mathrm{t}}$ and $\gamma_{\mathrm{i}}$ are time and industry dummies. All variables are in per hour terms. $^{16}$

The estimation of Eq. (1) is the basis to test our hypotheses. In particular, HP1 requires the coefficient of $\mathrm{K}^{\text {Intgs }}$ to be positive and significant when the dependent variable is participation in GVC (the sum of DVAFEX and FVADEX). HP2 is verified by allowing the coefficients on tangible, intangible and ICT investment to vary between manufacturing and service industries. We expect the coefficient on R\&D to be higher for manufacturing while we do not have strong a priori about the relative size of the coefficients for the other intangibles but we assume them to be significant also in services. HP3 requires a different impact of intangibles on the two measures of forward and backward

\footnotetext{
16 We prefer to standardize GVC variables for hours worked rather than for exports for comparability with other variables. Moreover, standardization by exports would not allow capturing whether investments in intangibles favours international competitiveness.
}

participation (i.e. a higher influence of marketing and advertising on backward compared to forward participation). To test this hypothesis, we nest the forward and backward participation equations in a single model, and we build a dummy variable equal to one for forward participation. We, then, estimate Eq. (1) where we include also all explanatory variables multiplied by the dummy variable so that the t-statistics on these variables test for the difference in the coefficients associated to forward and backward linkages.

Finally, HP4 presumes $\mathrm{K}^{\text {intgs }}$ to positively affect the ratio between forward and backward participation.

Given the small time coverage of our data, we report estimates of generalized least squares on data pooled across countries, industries and over time, controlling for industry and time fixed effects. The estimations can then be affected by problems of simultaneity bias arising when one or more of the explanatory variables are determined jointly with the dependent variable. It could be argued that firms/countries make decisions on investment in intangible assets partly based on their participa- 
Fig. 3

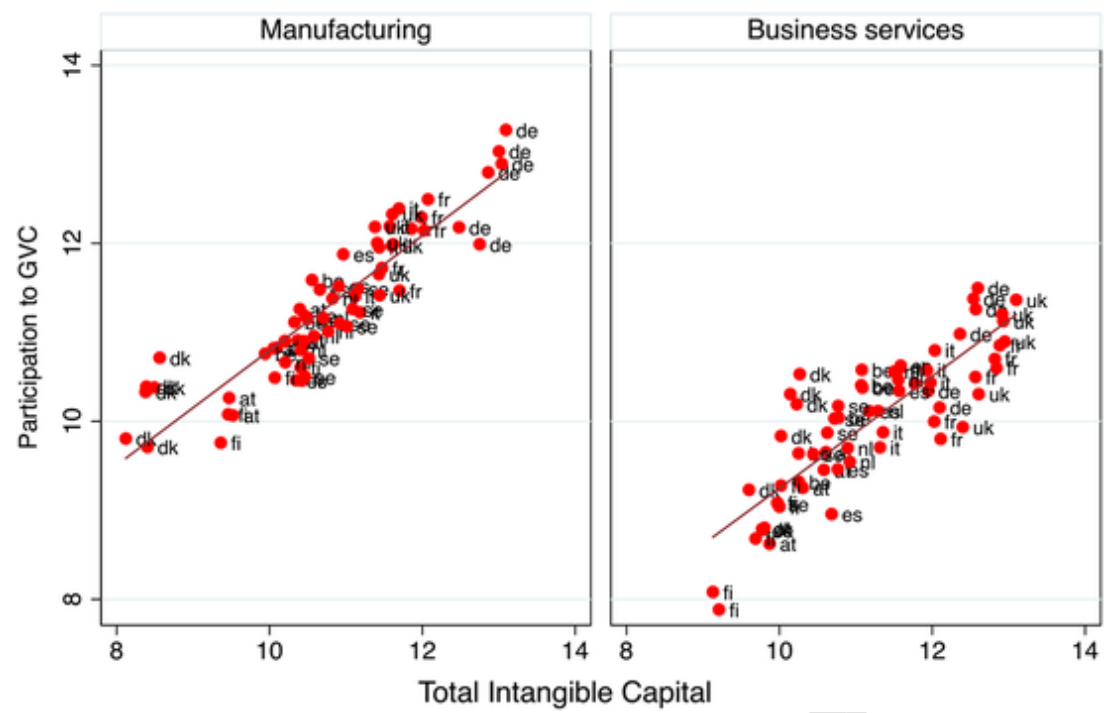

Participation in global value chains vs intangible capital.

Fig. 4
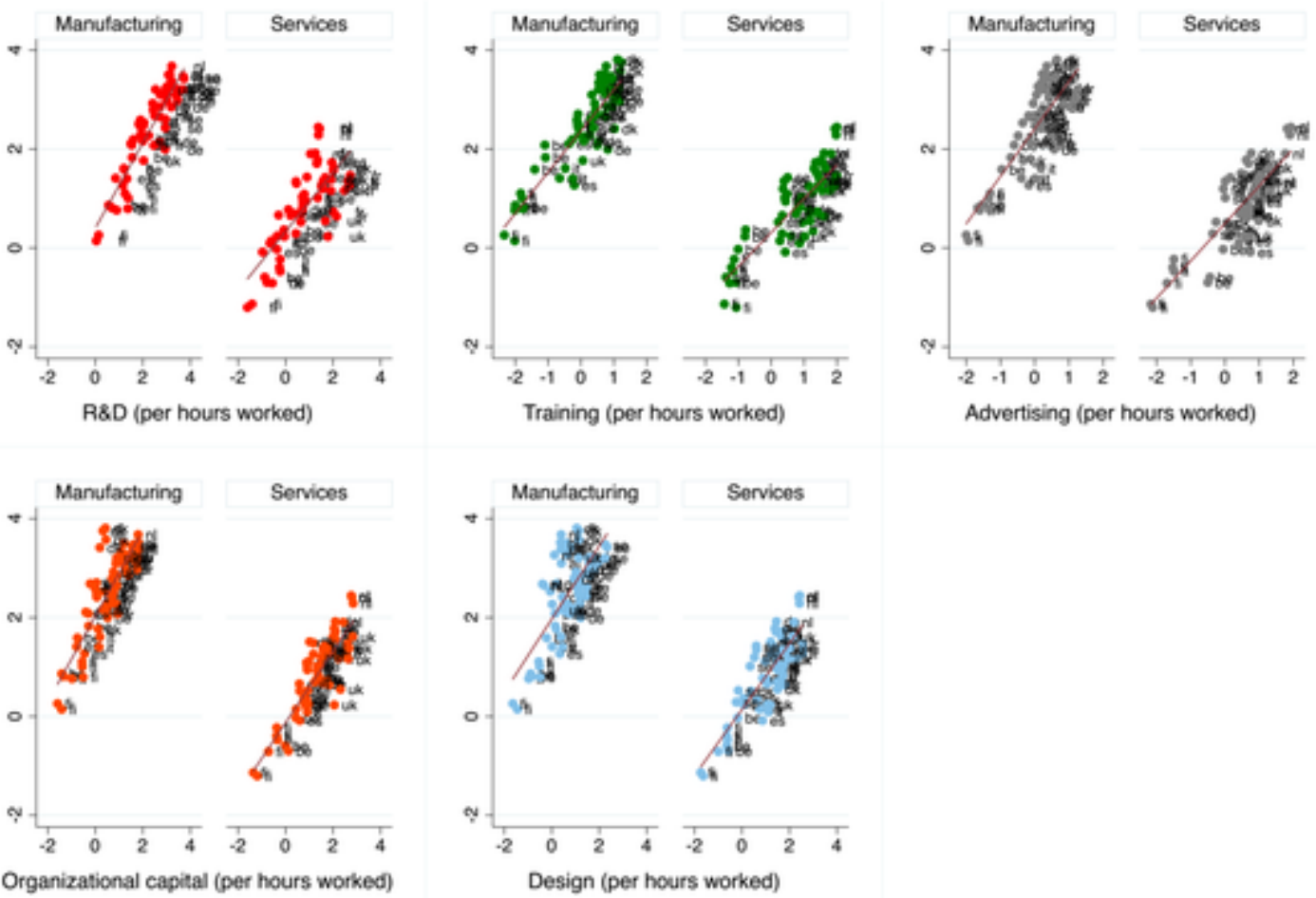

Forward participation in global value chains and intangible capital.

tion in GVC. One way of dealing with this problem is to use instrumental variables Ackerberg et al., 2015. However, since research on measurement of intangibles is still at an early stage, in the literature there are not consolidated instruments for intangible capital. Therefore, we follow a standard approach to deal with endogeneity. As in Corrado et al. (2017) we instrument intangible capital (and also tangible and ICT capital) with its lagged levels and time differences. ${ }^{17}$ The results of these estimations are reported in Appendix 2.

Finally, in Appendix 3, we also report robustness checks using measures of GVC participation based on final demand rather than exports.

\footnotetext{
17 Another option was to use Generalized Method of Moments (GMM). However, due to the short time series this would not give meaningful results (see also Draca et al., 2006 for a similar problem on productivity estimates).
} 
Fig. 5
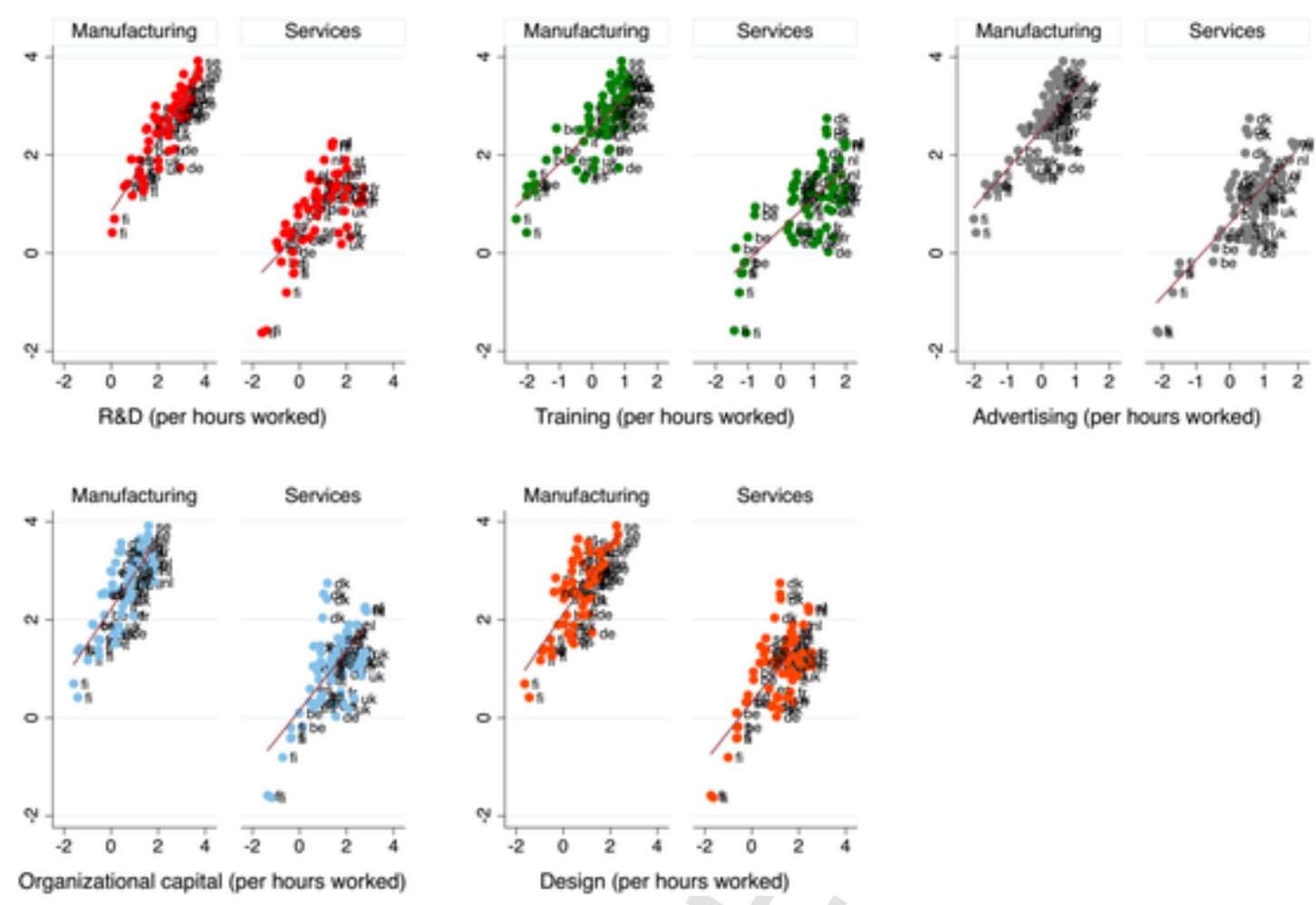

Backward participation in global value chains and intangible capital.

\section{Econometric results}

Our first set of results is reported in Table 1 where we investigate the determinants of participation in GVC, then we check if factors affecting participation differ between manufacturing and services (Table 2) and between forward and backward participation (Table 3); finally, we explore the relationship between intangible assets and value appropriation in GVC participation (Table 4).

Tables 1,2 and 4 show regression results for total intangible assets (column 1) and distinguishing between R\&D and other intangibles (columns 2, 3 and 4); then columns 5 to 8 analyze the individual effect of training, marketing and advertising, design and organizational capital. $^{18}$ Table 3 reports our findings for forward (columns 1 to 6 ) and backward (columns 7 to 12) participation and shows the differential impact of intangible assets on the two modes of participation.

Our first hypothesis is supported by the results shown in Table 1: total intangible assets positively affect participation in global value chains. This finding confirms the relevance of intangibles for the coordination and efficient organization of GVCs (Gereffi et al., 2005; Durand and Miller, 2018). It is also consistent with the view (Chen et al., 2018) that the patterns of specialization found in case studies like the iPod and showing that firms from advanced countries specialize in intangible intensive activities along the GVC, have implications at the country level: intangible capital allows advanced countries

18 The high correlation coefficients between the various intangibles make it impossible to consider all of them simultaneously in the same equation. to take part in GVCs by specialising in high-value-added functions.

Moreover, when looking separately at R\&D and non-R\&D intangible assets, they both contribute to participation in GVC. ${ }^{19}$ To judge the economic significance of our findings we look at the projected effects of R\&D and non-R\&D intangibles on GVC participation using columns (2) and (3) of Table 1 . The results imply a contribution of R\&D per hours worked to the intensity of GVC participation of 0.189 percentage points on average $(0.128 * 1.48=0.189)$. The contribution of non-R\&D intangibles is much larger: 1.44 percentage points on average $(0.639 * 2.26=1.44)$ which is quite sizeable considering the actual average value (in log) of GVC participation (2.26). The overall sizeable impact of non-R\&D intangibles, and particularly training (0.28) and organizational capital (0.24), suggest the strategic role of economic competencies, including firm-specific skills such as superior management and organizational structure, for GVC participation. These assets involve more tacit forms of knowledge and may therefore be more difficult to replicate than innovative property or computerized information (OECD, 2013b).

Also, tangible and ICT capital are positively related to participation in GVC pointing to the complementary role of tangible capital, intangible capital and ICT (Corrado et al., 2017).

Finally, as found in previous studies (Cheng et al., 2015; López-Gonzalez et al., 2015; WTO, 2014), small economies, countries with a lower income corporate tax rate and with a more competitive market (lower barriers to entrepreneurship, to trade and investment and lower state control) experience

19 However, when we control for their joint effect in a unique regression, R\&D remains significant but becomes negative as a likely consequence of collinearity between them. 
Table 1

The determinants of participation in GVC.

\begin{tabular}{|c|c|c|c|c|c|c|c|c|}
\hline & (1) & (2) & (3) & (4) & (5) & (6) & (7) & $(8)$ \\
\hline Variables & \multicolumn{6}{|c|}{ Dependent variable: $\ln \left(\mathrm{H}_{-} \mathrm{dvafex}+\mathrm{H}_{-}\right.$fvadex $)$} & & \\
\hline lnH_D_totintg & $\begin{array}{l}0.521^{* * *} \\
(0.035)\end{array}$ & & & & & & & \\
\hline lnH_D_k_ict & $\begin{array}{l}0.142^{* * *} \\
(0.051)\end{array}$ & $\begin{array}{l}0.426^{* * *} \\
(0.050)\end{array}$ & $\begin{array}{l}0.145^{* *} \\
(0.063)\end{array}$ & $\begin{array}{l}0.055 \\
(0.063)\end{array}$ & $\begin{array}{l}0.263^{* * *} \\
(0.050)\end{array}$ & $\begin{array}{l}0.153 \\
(0.094)\end{array}$ & $\begin{array}{l}0.426^{* * *} \\
(0.069)\end{array}$ & $\begin{array}{l}0.248^{* * *} \\
(0.064)\end{array}$ \\
\hline lnH_D_all_tang_kstock_k & $\begin{array}{l}0.469^{* * *} \\
(0.048)\end{array}$ & $\begin{array}{l}0.503^{* * *} \\
(0.064)\end{array}$ & $\begin{array}{l}0.292^{* * *} \\
(0.062)\end{array}$ & $\begin{array}{l}0.427^{* * *} \\
(0.068)\end{array}$ & $\begin{array}{l}0.160^{* * *} \\
(0.051)\end{array}$ & $\begin{array}{l}0.442^{* * *} \\
(0.067)\end{array}$ & $\begin{array}{l}0.381^{* * *} \\
(0.073)\end{array}$ & $\begin{array}{l}0.502^{* * *} \\
(0.060)\end{array}$ \\
\hline lnH_D_rd_kstock_k & & $\begin{array}{l}0.128^{* * *} \\
(0.035)\end{array}$ & & $\begin{array}{l}-0.087^{* 8} \\
(0.037)\end{array}$ & & & & \\
\hline lnH_D_intg_xrd_kstock & & & $\begin{array}{l}0.639^{* * *} \\
(0.064)\end{array}$ & $\begin{array}{l}0.724^{* * *} \\
(0.087)\end{array}$ & & & & \\
\hline lnH_D_train_kstock_k & & & & & $\begin{array}{l}0.530^{* * *} \\
(0.035)\end{array}$ & & & \\
\hline lnH_D_adv_mkt_kstock_k & & & & & & $\begin{array}{l}0.433^{* * *} \\
(0.072)\end{array}$ & & \\
\hline lnH_D_arch_des_kstock_k & & & & & & & $\begin{array}{l}0.223^{* * *} \\
(0.055)\end{array}$ & \\
\hline lnH_D_orgcap_kstock_k & & & & & & & & $\begin{array}{l}0.267^{* * *} \\
(0.038)\end{array}$ \\
\hline corporateincometaxrate & $\begin{array}{l}-0.010^{* * *} \\
(0.004)\end{array}$ & $\begin{array}{l}-0.010^{*} \\
(0.005)\end{array}$ & $\begin{array}{l}-0.013^{* * *} \\
(0.003)\end{array}$ & $\begin{array}{l}-0.015^{* * *} \\
(0.004)\end{array}$ & $\begin{array}{l}-0.009^{* * *} \\
(0.002)\end{array}$ & $\begin{array}{l}-0.014^{* * *} \\
(0.005)\end{array}$ & $\begin{array}{l}-0.013^{* *} \\
(0.006)\end{array}$ & $\begin{array}{l}-0.009^{* * *} \\
(0.004)\end{array}$ \\
\hline $\ln \_$pop & $\begin{array}{l}-0.200^{* * *} \\
(0.028)\end{array}$ & $\begin{array}{l}-0.184^{* * *} \\
(0.033)\end{array}$ & $\begin{array}{l}-0.234^{* * *} \\
(0.031)\end{array}$ & $\begin{array}{l}-0.245^{* * *} \\
(0.029)\end{array}$ & $\begin{array}{l}-0.232^{* * *} \\
(0.026)\end{array}$ & $\begin{array}{l}-0.140^{* * *} \\
(0.031)\end{array}$ & $\begin{array}{l}-0.198^{* * *} \\
(0.036)\end{array}$ & $\begin{array}{l}-0.152^{* * 8} \\
(0.030)\end{array}$ \\
\hline ln_eduexp & $\begin{array}{l}0.458^{* * 8} \\
(0.140)\end{array}$ & $\begin{array}{l}0.054 \\
(0.189)\end{array}$ & $\begin{array}{l}0.092 \\
(0.150)\end{array}$ & $\begin{array}{l}0.225 \\
(0.194)\end{array}$ & $\begin{array}{l}-0.194 \\
(0.156)\end{array}$ & $\begin{array}{l}0.358^{* *} \\
(0.167)\end{array}$ & $\begin{array}{l}0.089 \\
(0.176)\end{array}$ & $\begin{array}{l}0.159 \\
(0.157)\end{array}$ \\
\hline $\mathrm{pmr}$ & $\begin{array}{l}-0.152 \\
(0.093)\end{array}$ & $\begin{array}{l}-0.388^{* * *} \\
(0.122)\end{array}$ & $\begin{array}{l}-0.150 \\
(0.111)\end{array}$ & $\begin{array}{l}-0.235^{* *} \\
(0.111)\end{array}$ & $\begin{array}{l}-0.031 \\
(0.085)\end{array}$ & $\begin{array}{l}-0.452^{* * *} \\
(0.106)\end{array}$ & $\begin{array}{l}-0.499^{* * *} \\
(0.107)\end{array}$ & $\begin{array}{l}-0.261^{* *} \\
(0.109)\end{array}$ \\
\hline services & $\begin{array}{l}-2.185^{* * *} \\
(0.058)\end{array}$ & $\begin{array}{l}-2.388^{* * *} \\
(0.104)\end{array}$ & $\begin{array}{l}-2.568^{* * *} \\
(0.048)\end{array}$ & $\begin{array}{l}-2.860^{* * *} \\
(0.095)\end{array}$ & $\begin{array}{l}-2.423^{* * *} \\
(0.041)\end{array}$ & $\begin{array}{l}-2.246^{* * *} \\
(0.081)\end{array}$ & $\begin{array}{l}-2.548^{* * *} \\
(0.059)\end{array}$ & $\begin{array}{l}-2.473^{* * *} \\
(0.049)\end{array}$ \\
\hline 2000.year & $\begin{array}{l}0.363^{* * *} \\
(0.050)\end{array}$ & $\begin{array}{l}0.234^{* * *} \\
(0.052)\end{array}$ & $\begin{array}{l}0.348^{* * *} \\
(0.054)\end{array}$ & $\begin{array}{l}0.403^{* * *} \\
(0.053)\end{array}$ & $\begin{array}{l}0.299^{* * *} \\
(0.040)\end{array}$ & $\begin{array}{l}0.327^{* * *} \\
(0.066)\end{array}$ & $\begin{array}{l}0.211^{* * *} \\
(0.072)\end{array}$ & $\begin{array}{l}0.318^{* * *} \\
(0.057)\end{array}$ \\
\hline 2005.year & $\begin{array}{l}0.297^{* * *} \\
(0.071)\end{array}$ & $\begin{array}{l}0.014 \\
(0.075)\end{array}$ & $\begin{array}{l}0.287^{* * *} \\
(0.084)\end{array}$ & $\begin{array}{l}0.275^{* * *} \\
(0.084)\end{array}$ & $\begin{array}{l}0.416^{* * *} \\
(0.063)\end{array}$ & $\begin{array}{l}0.142 \\
(0.095)\end{array}$ & $\begin{array}{l}-0.076 \\
(0.084)\end{array}$ & $\begin{array}{l}0.216^{* *} \\
(0.085)\end{array}$ \\
\hline 2008.year & $\begin{array}{l}0.347^{* * *} \\
(0.090)\end{array}$ & $\begin{array}{l}-0.010 \\
(0.104)\end{array}$ & $\begin{array}{l}0.332^{* * *} \\
(0.109)\end{array}$ & $\begin{array}{l}0.293^{* * *} \\
(0.109)\end{array}$ & $\begin{array}{l}0.582^{* * *} \\
(0.091)\end{array}$ & $\begin{array}{l}0.157 \\
(0.118)\end{array}$ & $\begin{array}{l}-0.112 \\
(0.103)\end{array}$ & $\begin{array}{l}0.251^{* *} \\
(0.108)\end{array}$ \\
\hline 2009.year & $\begin{array}{l}0.064 \\
(0.090)\end{array}$ & $\begin{array}{l}-0.286^{* * *} \\
(0.103)\end{array}$ & $\begin{array}{l}0.080 \\
(0.110)\end{array}$ & $\begin{array}{l}0.051 \\
(0.112)\end{array}$ & $\begin{array}{l}0.339^{* * *} \\
(0.091)\end{array}$ & $\begin{array}{l}-0.060 \\
(0.122)\end{array}$ & $\begin{array}{l}-0.358^{* * *} \\
(0.103)\end{array}$ & $\begin{array}{l}-0.007 \\
(0.109)\end{array}$ \\
\hline 2010.year & $\begin{array}{l}0.181 \\
(0.156)\end{array}$ & $\begin{array}{l}-0.164 \\
(0.144)\end{array}$ & $\begin{array}{l}0.238 \\
(0.162)\end{array}$ & $\begin{array}{l}0.229 \\
(0.162)\end{array}$ & $\begin{array}{l}0.435^{* * *} \\
(0.136)\end{array}$ & $\begin{array}{l}0.116 \\
(0.163)\end{array}$ & $\begin{array}{l}-0.195 \\
(0.155)\end{array}$ & $\begin{array}{l}0.141 \\
(0.160)\end{array}$ \\
\hline Observations & 92 & 82 & 92 & 82 & 92 & 92 & 92 & 92 \\
\hline Number of ctrysec & 18 & 16 & 18 & 16 & 18 & 18 & 18 & 18 \\
\hline
\end{tabular}

Standard errors in parentheses.

**** $\mathrm{p}<0.01$.

** $\mathrm{p}<0.05$.

${ }^{*} \mathrm{p}<0.1$.

higher participation in GVC. On the other hand, the intensity of public expenditure in education is positive and significant only in few specifications. $^{20}$

Our second hypothesis about a differentiated effect between manufacturing and services is partially supported by estimates in Table 2 . As expected, R\&D is positively correlated to GVC participation only in manufacturing corroborating the view that R\&D insufficiently capture service innovation activities (Schricke et al., 2012; Tomlinson, 2000). Non-R\&D intangibles matter for participation both in manufacturing

in

ser-

20 Robustness checks using instrumental variables lead to very similar results (see Table A1 in the Appendix). vices, but the economic significance is higher in manufacturing $(0.78$ versus 0.26 , which predict respectively $33 \%$ and $11 \%$ of the average level of GVC participation). The interpretation of this result requires to consider that domestic and foreign value added in manufacturing exports include also indirect value added from business services used to produce manufacturing goods that are exported. Therefore, due to the 'servicification' of manufacturing (Lanz and Maurer, 2015; Miroudot and Cadestin, 2017), the high coefficient for manufacturing can hide an important role of intangibles also for indirect exports of business services.

Looking at ICT capital, we find, as expected, a larger economic significance for services ( 0.52 versus 0.03 , considering column (1) of Table 2), confirming that the information-based 
Table 2

The determinants of participation in GVC: differences between manufacturing and services.

\begin{tabular}{|c|c|c|c|c|c|c|c|c|}
\hline & (1) & $(2)$ & (3) & (4) & (5) & (6) & (7) & $(8)$ \\
\hline Variables & \multicolumn{6}{|c|}{ Dependent variable: $\ln \left(H_{-} d v a f e x+H_{-}\right.$fvadex $)$} & & \\
\hline lnH_D_totintgman & $\begin{array}{l}\mathbf{0 . 5 9 9}^{* * *} \\
(0.028)\end{array}$ & & & & & & & \\
\hline lnH_D_totintgser & $\begin{array}{l}\mathbf{0 . 1 8 2}^{* * *} \\
(0.070)\end{array}$ & & & & & & & \\
\hline lnH_D_rd_kstock_k_man & & $\begin{array}{l}\mathbf{0 . 4 0 2}^{* * *} \\
(0.036)\end{array}$ & & $\begin{array}{l}\mathbf{0 . 2 1 9}^{* * *} \\
(0.054)\end{array}$ & & & & \\
\hline lnH_D_rd_kstock_k_ser & & $\begin{array}{l}-0.003 \\
(0.036)\end{array}$ & & $\begin{array}{l}-0.158^{* * *} \\
(0.036)\end{array}$ & & & & \\
\hline lnH_D_intg_xrd_kstock_man & & & $\begin{array}{l}\mathbf{0 . 9 1 9} \\
(0.088)\end{array}$ & $\begin{array}{l}0.430^{* * *} \\
(0.120)\end{array}$ & & & & \\
\hline lnH_D_intg_xrd_kstock_ser & & & $\begin{array}{l}\mathbf{0 . 3 1 8}^{* * *} \\
(0.076)\end{array}$ & $\begin{array}{l}\mathbf{0 . 6 2 3}^{* * *} \\
(0.092)\end{array}$ & & & & \\
\hline lnH_D_train_kstock_k_man & & & & & $\begin{array}{l}0.575^{* * *} \\
(0.044)\end{array}$ & & & \\
\hline lnH_D_train_kstock_k_ser & & & & & $\begin{array}{l}0.496^{* * *} \\
(0.059)\end{array}$ & & & \\
\hline lnH_D_adv_mkt_kstock_k_man & & & & & & $\begin{array}{l}\mathbf{0 . 5 7 7} \\
(0.092)\end{array}$ & & \\
\hline lnH_D_adv_mkt_kstock_k_ser & & & & & & $\begin{array}{l}\mathbf{0 . 2 8 3}^{* *} \\
(0.113)\end{array}$ & & \\
\hline lnH_D_arch_des_kstock_k_man & & & & & & & $\begin{array}{l}\mathbf{0 . 4 2 5}^{* * *} \\
(0.080)\end{array}$ & \\
\hline lnH_D_arch_des_kstock_k_ser & & & & & & & $\begin{array}{l}\mathbf{0 . 1 1 0} \\
(0.087)\end{array}$ & \\
\hline lnH_D_orgcap_kstock_k_man & & & & & & & & $\begin{array}{l}\mathbf{0 . 4 7 2}^{* * *} \\
(0.058)\end{array}$ \\
\hline lnH_D_orgcap_kstock_k_ser & & & & & & & & $\begin{array}{l}\mathbf{0 . 1 5 2}^{* * *} \\
(0.044)\end{array}$ \\
\hline lnH_D_k_ict_man & $\begin{array}{l}\mathbf{0 . 0 7 9}^{*} \\
(0.044)\end{array}$ & $\begin{array}{l}\mathbf{0 . 1 6 8}^{* * *} \\
(0.051)\end{array}$ & $\begin{array}{l}\mathbf{0 . 0 1 5} \\
(0.067)\end{array}$ & $\begin{array}{l}\mathbf{0 . 0 2 2} \\
(0.053)\end{array}$ & $\begin{array}{l}\mathbf{0 . 1 8 8}^{* * *} \\
(0.062)\end{array}$ & $\begin{array}{l}0.104 \\
(0.101)\end{array}$ & $\begin{array}{l}\mathbf{0 . 4 0 2} \\
(0.083)\end{array}$ & $\begin{array}{l}\mathbf{0 . 0 8 3} \\
(0.065)\end{array}$ \\
\hline lnH_D_k_ict_ser & $\begin{array}{l}\mathbf{0 . 4 7 1} 1^{* * *} \\
(0.083)\end{array}$ & $\begin{array}{l}\mathbf{0 . 4 9 3}^{* * *} \\
(0.082)\end{array}$ & $\begin{array}{l}0.423^{* * *} \\
(0.084)\end{array}$ & $\begin{array}{l}\mathbf{0 . 1 4 8} \\
(0.081)\end{array}$ & $\begin{array}{l}\mathbf{0 . 3 5 9}^{* * *} \\
(0.067)\end{array}$ & $\begin{array}{l}0.275^{* *} \\
(0.140)\end{array}$ & $\begin{array}{l}\mathbf{0 . 6 4 3}^{* * *} \\
(0.103)\end{array}$ & $\begin{array}{l}\mathbf{0 . 4 2 4 ^ { * * * }} \\
(0.083)\end{array}$ \\
\hline lnH_D_all_tang_kstock_k_man & $\begin{array}{l}0.501^{* * *} \\
(0.037)\end{array}$ & $\begin{array}{l}0.589^{* * *} \\
(0.051)\end{array}$ & $\begin{array}{l}0.218^{* * *} \\
(0.058)\end{array}$ & $\begin{array}{l}0.506^{* * *} \\
(0.053)\end{array}$ & $\begin{array}{l}0.183^{* * *} \\
(0.052)\end{array}$ & $\begin{array}{l}0.388^{* * *} \\
(0.074)\end{array}$ & $\begin{array}{l}0.308^{* * *} \\
(0.081)\end{array}$ & $\begin{array}{l}0.517^{* * *} \\
(0.054)\end{array}$ \\
\hline lnH_D_all_tang_kstock_k_ser & $\begin{array}{l}0.382^{* * *} \\
(0.104)\end{array}$ & $\begin{array}{l}0.531^{* * *} \\
(0.111)\end{array}$ & $\begin{array}{l}0.317^{* * * *} \\
(0.104)\end{array}$ & $\begin{array}{l}0.487^{* * *} \\
(0.106)\end{array}$ & $\begin{array}{l}0.087 \\
(0.111)\end{array}$ & $\begin{array}{l}0.479^{* * *} \\
(0.119)\end{array}$ & $\begin{array}{l}0.226^{*} \\
(0.125)\end{array}$ & $\begin{array}{l}0.416^{* * *} \\
(0.109)\end{array}$ \\
\hline corporateincometaxrate & $\begin{array}{l}-0.010^{* * *} \\
(0.004)\end{array}$ & $\begin{array}{l}-0.011^{* *} \\
(0.004)\end{array}$ & $\begin{array}{l}-0.010^{* *} \\
(0.004)\end{array}$ & $\begin{array}{l}-0.012^{* * *} \\
(0.003)\end{array}$ & $\begin{array}{l}-0.006^{* *} \\
(0.003)\end{array}$ & $\begin{array}{l}-0.014^{* * *} \\
(0.005)\end{array}$ & $\begin{array}{l}-0.014^{* *} \\
(0.006)\end{array}$ & $\begin{array}{l}-0.011^{* *} \\
(0.005)\end{array}$ \\
\hline $\ln$ _pop & $\begin{array}{l}-0.195^{* * *} \\
(0.026)\end{array}$ & $\begin{array}{l}-0.155^{* * *} \\
(0.028)\end{array}$ & $\begin{array}{l}-0.275^{* * *} \\
(0.033)\end{array}$ & $\begin{array}{l}-0.211^{* * *} \\
(0.026)\end{array}$ & $\begin{array}{l}-0.235^{* * *} \\
(0.029)\end{array}$ & $\begin{array}{l}-0.176^{* * *} \\
(0.039)\end{array}$ & $\begin{array}{l}-0.231^{* * *} \\
(0.041)\end{array}$ & $\begin{array}{l}-0.160^{* * *} \\
(0.029)\end{array}$ \\
\hline lneduexp & $\begin{array}{l}0.592^{* * *} \\
(0.127)\end{array}$ & $\begin{array}{l}0.519^{* *} \\
(0.215)\end{array}$ & $\begin{array}{l}0.165 \\
(0.135)\end{array}$ & $\begin{array}{l}0.624^{* * *} \\
(0.176)\end{array}$ & $\begin{array}{l}-0.173 \\
(0.162)\end{array}$ & $\begin{array}{l}0.234 \\
(0.193)\end{array}$ & $\begin{array}{l}0.097 \\
(0.183)\end{array}$ & $\begin{array}{l}0.295^{*} \\
(0.157)\end{array}$ \\
\hline $\mathrm{pmr}$ & $\begin{array}{l}-0.224^{* *} \\
(0.093)\end{array}$ & $\begin{array}{l}-0.408^{* * *} \\
(0.115)\end{array}$ & $\begin{array}{l}-0.249^{* *} \\
(0.105)\end{array}$ & $\begin{array}{l}-0.285^{* * *} \\
(0.108)\end{array}$ & $\begin{array}{l}-0.005 \\
(0.101)\end{array}$ & $\begin{array}{l}-0.503^{* * *} \\
(0.119)\end{array}$ & $\begin{array}{l}-0.426^{* * *} \\
(0.119)\end{array}$ & $\begin{array}{l}-0.242^{* *} \\
(0.112)\end{array}$ \\
\hline services & $\begin{array}{l}-1.271^{* * *} \\
(0.328)\end{array}$ & $\begin{array}{l}-1.864^{* * *} \\
(0.351)\end{array}$ & $\begin{array}{l}-2.350^{* * *} \\
(0.338)\end{array}$ & $\begin{array}{l}-2.554^{* * *} \\
(0.343)\end{array}$ & $\begin{array}{l}-2.204^{* * *} \\
(0.380)\end{array}$ & $\begin{array}{l}-2.888^{* * *} \\
(0.484)\end{array}$ & $\begin{array}{l}-2.333^{* * *} \\
(0.444)\end{array}$ & $\begin{array}{l}-2.287^{* * *} \\
(0.370)\end{array}$ \\
\hline 2000.year & $\begin{array}{l}0.326^{* * *} \\
(0.046)\end{array}$ & $\begin{array}{l}0.307^{* * *} \\
(0.055)\end{array}$ & $\begin{array}{l}0.315^{* * *} \\
(0.054)\end{array}$ & $\begin{array}{l}0.425^{* * *} \\
(0.046)\end{array}$ & $\begin{array}{l}0.278^{* * *} \\
(0.048)\end{array}$ & $\begin{array}{l}0.324^{* * *} \\
(0.077)\end{array}$ & $\begin{array}{l}0.171^{* *} \\
(0.076)\end{array}$ & $\begin{array}{l}0.301^{* * *} \\
(0.063)\end{array}$ \\
\hline 2005.year & $\begin{array}{l}0.206^{* * *} \\
(0.064)\end{array}$ & $\begin{array}{l}0.043 \\
(0.075)\end{array}$ & $\begin{array}{l}0.227^{* * *} \\
(0.081)\end{array}$ & $\begin{array}{l}0.277^{* * *} \\
(0.076)\end{array}$ & $\begin{array}{l}0.432^{* * *} \\
(0.069)\end{array}$ & $\begin{array}{l}0.133 \\
(0.106)\end{array}$ & $\begin{array}{l}-0.129 \\
(0.088)\end{array}$ & $\begin{array}{l}0.195^{* *} \\
(0.084)\end{array}$ \\
\hline 2008.year & $\begin{array}{l}0.255^{* * *} \\
(0.080)\end{array}$ & $\begin{array}{l}0.050 \\
(0.097)\end{array}$ & $\begin{array}{l}0.241^{* *} \\
(0.102)\end{array}$ & $\begin{array}{l}0.322^{* * *} \\
(0.099)\end{array}$ & $\begin{array}{l}0.625^{* * *} \\
(0.097)\end{array}$ & $\begin{array}{l}0.130 \\
(0.130)\end{array}$ & $\begin{array}{l}-0.164 \\
(0.105)\end{array}$ & $\begin{array}{l}0.228^{* *} \\
(0.103)\end{array}$ \\
\hline 2009.year & $\begin{array}{l}-0.038 \\
(0.081)\end{array}$ & $\begin{array}{l}-0.232^{* *} \\
(0.097)\end{array}$ & $\begin{array}{l}-0.011 \\
(0.103)\end{array}$ & $\begin{array}{l}0.064 \\
(0.100)\end{array}$ & $\begin{array}{l}0.377^{* * *} \\
(0.098)\end{array}$ & $\begin{array}{l}-0.093 \\
(0.134)\end{array}$ & $\begin{array}{l}-0.422^{* * *} \\
(0.106)\end{array}$ & $\begin{array}{l}-0.019 \\
(0.103)\end{array}$ \\
\hline 2010.year & $\begin{array}{l}0.068 \\
(0.128)\end{array}$ & $\begin{array}{l}-0.101 \\
(0.136)\end{array}$ & $\begin{array}{l}0.122 \\
(0.136)\end{array}$ & $\begin{array}{l}0.183 \\
(0.152)\end{array}$ & $\begin{array}{l}0.502^{* * *} \\
(0.123)\end{array}$ & $\begin{array}{l}0.082 \\
(0.164)\end{array}$ & $\begin{array}{l}-0.291^{* *} \\
(0.148)\end{array}$ & $\begin{array}{l}0.124 \\
(0.140)\end{array}$ \\
\hline Observations & 92 & 82 & 92 & 82 & 92 & 92 & 92 & 92 \\
\hline Number of ctrysec & 18 & 16 & 18 & 16 & 18 & 18 & 18 & 18 \\
\hline
\end{tabular}


Standard errors in parentheses.

Bold indicates significant differences between the coefficient on manufacturing and that on services at $10 \%$.

**** $\mathrm{p}<0.01$.

*** $\mathrm{p}<0.05$.

* $\mathrm{p}<0.1$.

nature of services gives to the generation and use of ICT a central role in firms/countries innovation activities (Evangelista, 2000; Guerrieri and Meliciani, 2005). Finally, investment in tangible assets is important both in manufacturing and in services.

When looking separately at forward and backward participation (Table 3), we mainly find support for our third hypothesis. As expected, all intangible assets contribute positively to both forward and backward participation, consistently with their complementary role (Corrado et al., 2017; Corrado and Hao, 2014). The coefficient for brand is significantly higher for backward than for forward participation confirming that investment in marketing and advertising is more important for exporting final than intermediate products. A similar result is also found for design. Finally, while we did not have any a priori expectation on training and organizational capital, we find that their coefficients are significantly higher for forward than for backward participation, suggesting they are key assets especially for generating domestic value added.

As far as other assets are concerned, ICT is a key factor for backward participation (a country to rely strongly on foreign inputs needs to have an efficient information and communication network) while tangible capital contributes more to forward participation. Small countries have higher participation in GVC both backward and forward but the negative effect of size is larger for backward participation. This is in line with the assumption that smaller countries tend to exhibit relatively lower domestic than foreign content of exports (Kowalski et al., 2015). Finally, while high corporate income taxes discourage both forward and backward participation, product market regulation has a relatively stronger impact on forward participation. ${ }^{21}$

The analysis developed so far supports the assumption that intangible capital matters to take part in global value chains in the European economies. Then we may ask whether intangibles also contribute to the appropriation of a greater share of value added created in a GVC. We expect that since value appropriation varies according to the ability of participants to supply sophisticated products or services, countries investing more in intangible assets have a comparative advantage in producing such products or services. Table 4 reports estimates of the value appropriation from participation measured as the ratio between domestic value added embodied in foreign exports and foreign value added embodied in domestic exports. The idea is that the higher is domestic value added compared to foreign value added, the higher is the domestic appropriation of value along the value chain.

Our findings show that intangible capital is positively related to value appropriation and this result is robust to introducing separately $R \& D$ and non-R\&D intangible assets. It appears that countries with a larger number of intangible-intensive firms reap a higher share of value added from participation in global supply chains since firms controlling such assets are able to generate higher returns (Mudambi, 2008)

$$
\text { and, }
$$
due

to

21 Robustness checks using instrumental variables lead to very similar results (see Table A2 in the Appendix). scale economies, receive a disproportionate share of the gains from the network as output expands (Durand and Miller, 2018). However, not all intangibles are equally relevant: training and organizational capital have a large positive effect while brand does not matter and design has a negative impact. The big role of organizational capital in affecting value appropriation in GVC confirms the importance of governance for extracting maximum rents (Gereffi et al., 2005). This result is also consistent with the sizeable contribution of organizational capital for export specialization in skill intensive industries (OECD, 2013a) and with the positive impact of managerial practices on firms' productivity and profitability and on countries' total factor productivity (Bloom et al., 2016; Bloom and Van Reenen, 2007).

The result for training points to the key function of firm specific human capital not only for taking part in GVC but also for value appropriation at the country level, consistently with the relevance of human capital for absorptive capacity (Lund Vinding, 2006).

Looking at the other variables, tangible capital, population, the intensity of public expenditure in education and a more competitive market (lower barriers to entrepreneurship, to trade and investment and lower state control) positively affect value appropriation from participation. These results are consistent with those of Cheng et al. (2015) who find that expanding the share of the domestic value added in a value chain require efforts to reduce trade barriers, enhance infrastructure, foster human capital formation, support research and development, and improve institutions. Surprisingly, we also find that ICT has a negative impact in most specifications. A possible explanation is that investment in information and communication technologies is particularly important for countries acting as export platforms, i.e. trading in international markets goods and services embodying high levels of foreign value added.

\section{Conclusions}

A recent stream of literature has emphasized the importance of knowledge based capital namely R\&D but also organizational capital, training, marketing and advertising for firms', industries' and countries' productivity growth. At the same time, a growing field of research has highlighted how the globalisation of value chains has changed the traditional factors of international competitiveness with different benefits accruing to different firms and countries depending on the tasks performed within the value chain. This paper is a first attempt at bridging the two streams of literature by investigating whether and how intangible capital contributes to foster advanced countries' participation in global value chains and their capability to appropriate value added along the supply chain. Our main findings can be summarized as follows.

First, intangible capital as a whole is positively related to participation in global value chains in advanced countries and is complementary to tangible capital and ICT. Moreover, non-R\&D intangibles play a larger role than R\&D with training being the main driver of participation.

Secondly, there are differences and similarities between manufacturing and services: while non-R\&D intangibles matter for both services and manufacturing, R\&D drives participation 
Table 3

The determinants of forward and backward participation.

\begin{tabular}{|c|c|c|c|c|c|c|c|c|c|c|c|c|}
\hline & (1) & (2) & (3) & (4) & (5) & (6) & (7) & (8) & (9) & (10) & (11) & (12) \\
\hline Variables & (lnH_dvafex) & (lnH_fvadex) & (lnH_dvafex) & (lnH_fvadex) & (lnH_dvafex) & (InH_fvadex) & (lnH_dvafex) & (lnH_fvadex) & (lnH_dvafex) & (InH_fvadex) & (lnH_dvafex) & (InH_fvadex) \\
\hline lnH_D_totintg & $\begin{array}{l}0.482^{* * *} \\
(0.051)\end{array}$ & $\begin{array}{l}0.389^{* * *} \\
(0.072)\end{array}$ & & & & & & & & & & \\
\hline lnH_D_rd_kstock_k & & & $\begin{array}{l}0.169^{* * * *} \\
(0.047)\end{array}$ & $\begin{array}{l}0.105^{* *} \\
(0.046)\end{array}$ & & & & & & & & \\
\hline lnH_D_train_kstock_k & & & & & $\begin{array}{l}0.643^{* * *} \\
(0.055)\end{array}$ & $\begin{array}{l}0.447^{* * *} \\
(0.089)\end{array}$ & & & & & & \\
\hline lnH_D_adv_mkt_kstock_k & & & & & & & $\begin{array}{l}\mathbf{0 . 2 6 9} \mathbf{9}^{* * *} \\
(0.102)\end{array}$ & $\begin{array}{l}\mathbf{0 . 5 6 9 * *} \\
(0.107)\end{array}$ & & & & \\
\hline InH_D_arch_des_kstock_k & & & & & & & & & $\begin{array}{l}\mathbf{0 . 1 6 0 * *} \\
(0.077)\end{array}$ & $\begin{array}{l}\mathbf{0 . 3 7 0}^{* * *} \\
(0.083)\end{array}$ & & \\
\hline lnH_D_orgcap_kstock_k & & & & & & & & & & & $\begin{array}{l}\mathbf{0 . 3 9 3} 3^{* * *} \\
(0.047)\end{array}$ & $\begin{array}{l}\mathbf{0 . 1 9 3} 3^{* * *} \\
(0.069)\end{array}$ \\
\hline lnH_D_k_ict & $\begin{array}{l}\mathbf{0 . 0 1 6} \\
(0.072)\end{array}$ & 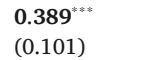 & 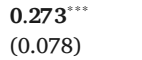 & $\begin{array}{l}0.566^{* * *} \\
(0.077)\end{array}$ & $\begin{array}{l}\mathbf{0 . 0 4 7} \\
(0.061)\end{array}$ & $\begin{array}{l}\mathbf{0 . 4 5 0} 0^{* * *} \\
(0.099)\end{array}$ & $\begin{array}{l}0.145 \\
(0.119)\end{array}$ & $\begin{array}{l}0.202 \\
(0.124)\end{array}$ & $\begin{array}{l}0.277^{* * *} \\
(0.095)\end{array}$ & $\begin{array}{l}0.463^{* * *} \\
(0.102)\end{array}$ & $\begin{array}{l}\mathbf{0 . 0 3 6} \\
(0.077)\end{array}$ & $\begin{array}{l}\mathbf{0 . 5 1 0}^{* * * *} \\
(0.112)\end{array}$ \\
\hline lnH_D_all_tang_kstock_k & $\begin{array}{l}0.625^{* * *} \\
(0.066)\end{array}$ & $\begin{array}{l}\mathbf{0 . 3 0 8} \\
(0.093)\end{array}$ & $\begin{array}{l}0.672^{* * *} \\
(0.096)\end{array}$ & $\begin{array}{l}\mathbf{0 . 3 8 2} \\
(0.095)\end{array}$ & $\begin{array}{l}0.218^{* * *} \\
(0.066)\end{array}$ & $\begin{array}{l}0.020 \\
(0.107)\end{array}$ & $\begin{array}{l}\mathbf{0 . 5 6 9} \\
(0.089)\end{array}$ & $\begin{array}{l}\mathbf{0 . 2 4 0 *} \\
(0.093)\end{array}$ & 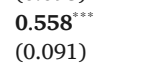 & 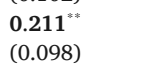 & $\begin{array}{l}0.617^{* * *} \\
(0.070)\end{array}$ & $\begin{array}{l}0.291^{* * *} \\
(0.102)\end{array}$ \\
\hline ln_pop & $\begin{array}{l}-0.104^{* * *} \\
(0.034)\end{array}$ & $\begin{array}{l}-0.305^{* * *} \\
(0.048)\end{array}$ & $\begin{array}{l}-0.097^{* *} \\
(0.044)\end{array}$ & $\begin{array}{l}-0.299^{* * *} \\
(0.043)\end{array}$ & $\begin{array}{l}-0.176^{* * *} \\
(0.032)\end{array}$ & $\begin{array}{l}-0.352^{* * *} \\
(0.051)\end{array}$ & $\begin{array}{l}-0.073 \\
(0.046)\end{array}$ & $\begin{array}{l}-0.284^{* * *} \\
(0.048)\end{array}$ & $\begin{array}{l}-0.111^{* *} \\
(0.051)\end{array}$ & $\begin{array}{l}-0.372^{2 *} \\
(0.054)\end{array}$ & $\begin{array}{l}-0.072^{*} \\
(0.036)\end{array}$ & $\begin{array}{l}-0.279^{* * *} \\
(0.053)\end{array}$ \\
\hline Ineduexp & $\begin{array}{l}0.436^{* * *} \\
(0.169)\end{array}$ & $\begin{array}{l}0.269 \\
(0.239)\end{array}$ & $\begin{array}{l}0.444 \\
(0.356)\end{array}$ & $\begin{array}{l}-0.261 \\
(0.351)\end{array}$ & $\begin{array}{l}-0.556^{* * *} \\
(0.147)\end{array}$ & $\begin{array}{l}-0.483^{* *} \\
(0.237)\end{array}$ & $\begin{array}{l}0.066 \\
(0.226)\end{array}$ & $\begin{array}{l}0.203 \\
(0.237)\end{array}$ & $\begin{array}{l}-0.128 \\
(0.219)\end{array}$ & $\begin{array}{l}-0.209 \\
(0.234)\end{array}$ & $\begin{array}{l}0.330^{*} \\
(0.178)\end{array}$ & $\begin{array}{l}0.043 \\
(0.260)\end{array}$ \\
\hline $\mathrm{pmr}$ & $\begin{array}{l}-0.527^{* * *} \\
(0.102)\end{array}$ & $\begin{array}{l}\mathbf{0 . 1 0 7} \\
(0.145)\end{array}$ & $\begin{array}{l}-0.690^{* * *} \\
(0.136)\end{array}$ & $\begin{array}{l}-0.061 \\
(0.134)\end{array}$ & $\begin{array}{l}-0.276^{* * *} \\
(0.098)\end{array}$ & $\begin{array}{l}\mathbf{0 . 2 5 6} \\
(0.158)\end{array}$ & $\begin{array}{l}-0.725^{* * *} \\
(0.135)\end{array}$ & $\begin{array}{l}-0.006 \\
(0.142)\end{array}$ & $\begin{array}{l}-0.737^{* * *} \\
(0.137)\end{array}$ & $\begin{array}{l}-0.029 \\
(0.147)\end{array}$ & $\begin{array}{l}-0.433^{* * *} \\
(0.113)\end{array}$ & $\begin{array}{l}\mathbf{0 . 0 7 9} \\
(0.166)\end{array}$ \\
\hline services & $\begin{array}{l}-2.170^{* * *} \\
(0.068)\end{array}$ & $\begin{array}{l}-2.386^{* . * *} \\
(0.096)\end{array}$ & $\begin{array}{l}-2.187^{* * *} \\
(0.143)\end{array}$ & $\begin{array}{l}-2.5599^{*} \\
(0.141)\end{array}$ & $\begin{array}{l}-2.299^{* *} \\
(0.056)\end{array}$ & $\begin{array}{l}-2.509^{* * *} \\
(0.090)\end{array}$ & $\begin{array}{l}-2.284^{* * *} \\
(0.107)\end{array}$ & $\begin{array}{l}-2.239^{* * *} \\
(0.112)\end{array}$ & $\begin{array}{l}-2.431^{* * *} \\
(0.085)\end{array}$ & $\begin{array}{l}-2.543^{* * *} \\
(0.091)\end{array}$ & $\begin{array}{l}-2.411^{* * *} \\
(0.064)\end{array}$ & $\begin{array}{l}-2.598^{* * s} \\
(0.095)\end{array}$ \\
\hline 2000.year & $\begin{array}{l}0.401^{* * *} \\
(0.076)\end{array}$ & $\begin{array}{l}0.194^{*} \\
(0.107)\end{array}$ & $\begin{array}{l}0.270^{* * * 3} \\
(0.097)\end{array}$ & $\begin{array}{l}0.091 \\
(0.096)\end{array}$ & $\begin{array}{l}0.356^{* * *} \\
(0.066)\end{array}$ & $\begin{array}{l}0.140 \\
(0.107)\end{array}$ & $\begin{array}{l}0.276^{* * *} \\
(0.103)\end{array}$ & $\begin{array}{l}0.191^{\prime} \\
(0.107)\end{array}$ & $\begin{array}{l}0.237^{* *} \\
(0.101)\end{array}$ & $\begin{array}{l}0.116 \\
(0.109)\end{array}$ & $\begin{array}{l}\mathbf{0 . 3 6 0} 0^{* * *} \\
(0.080)\end{array}$ & $\begin{array}{l}\mathbf{0 . 1 1 1} \\
(0.117)\end{array}$ \\
\hline 2005.year & $\begin{array}{l}0.206^{* *} \\
(0.086)\end{array}$ & $\begin{array}{l}0.146 \\
(0.122)\end{array}$ & $\begin{array}{l}-0.097 \\
(0.106)\end{array}$ & $\begin{array}{l}-0.037 \\
(0.105)\end{array}$ & $\begin{array}{l}0.510^{* * *} \\
(0.088)\end{array}$ & $\begin{array}{l}0.328^{* *} \\
(0.141)\end{array}$ & $\begin{array}{l}0.084 \\
(0.123)\end{array}$ & $\begin{array}{l}0.237^{\circ} \\
(0.129)\end{array}$ & $\begin{array}{l}-0.033 \\
(0.113)\end{array}$ & $\begin{array}{l}-0.005 \\
(0.121)\end{array}$ & $\begin{array}{l}0.239^{* 3} \\
(0.094)\end{array}$ & $\begin{array}{l}0.078 \\
(0.138)\end{array}$ \\
\hline 2008.year & $\begin{array}{l}0.199^{* *} \\
(0.101)\end{array}$ & $\begin{array}{l}0.275^{*} \\
(0.143)\end{array}$ & $\begin{array}{l}-0.173 \\
(0.131)\end{array}$ & $\begin{array}{l}0.056 \\
(0.130)\end{array}$ & $\begin{array}{l}0.698^{* * *} \\
(0.109)\end{array}$ & $\begin{array}{l}0.591^{* * s} \\
(0.176)\end{array}$ & $\begin{array}{l}0.080 \\
(0.146)\end{array}$ & $\begin{array}{l}0.105^{* * *} \\
(0.153)\end{array}$ & $\begin{array}{l}-0.070 \\
(0.133)\end{array}$ & $\begin{array}{l}0.092 \\
(0.142)\end{array}$ & $\begin{array}{l}0.245^{* *} \\
(0.110)\end{array}$ & $\begin{array}{l}0.206 \\
(0.161)\end{array}$ \\
\hline 2009.year & $\begin{array}{l}-0.016 \\
(0.101)\end{array}$ & $\begin{array}{l}-0.003 \\
(0.144)\end{array}$ & $\begin{array}{l}-0.389^{* * *} \\
(0.131)\end{array}$ & $\begin{array}{l}-0.224^{*} \\
(0.130)\end{array}$ & $\begin{array}{l}0.487^{* * *} \\
(0.110)\end{array}$ & $\begin{array}{l}0.314^{*} \\
(0.177)\end{array}$ & $\begin{array}{l}-0.115 \\
(0.151)\end{array}$ & $\begin{array}{l}0.176 \\
(0.158)\end{array}$ & $\begin{array}{l}-0.290^{* *} \\
(0.133)\end{array}$ & $\begin{array}{l}-0.190 \\
(0.143)\end{array}$ & $\begin{array}{l}0.033 \\
(0.111)\end{array}$ & $\begin{array}{l}-0.072 \\
(0.163)\end{array}$ \\
\hline 2010.year & $\begin{array}{l}0.135 \\
(0.166)\end{array}$ & $\begin{array}{l}-0.018 \\
(0.235)\end{array}$ & $\begin{array}{l}-0.240 \\
(0.205)\end{array}$ & $\begin{array}{l}-0.106 \\
(0.202)\end{array}$ & $\begin{array}{l}0.637^{* * *} \\
(0.161)\end{array}$ & $\begin{array}{l}0.296 \\
(0.260)\end{array}$ & $\begin{array}{l}0.029 \\
(0.234)\end{array}$ & $\begin{array}{l}0.161 \\
(0.246)\end{array}$ & $\begin{array}{l}-0.154 \\
(0.225)\end{array}$ & $\begin{array}{l}-0.221 \\
(0.241)\end{array}$ & $\begin{array}{l}0.174 \\
(0.179)\end{array}$ & $\begin{array}{l}-0.097 \\
(0.262)\end{array}$ \\
\hline Observations & 92 & 92 & 82 & 82 & 92 & 92 & 92 & 92 & 92 & 92 & 92 & 92 \\
\hline Number of ctrysec & $18<$ & 18 & 16 & 16 & 18 & 18 & 18 & 18 & 18 & 18 & 18 & 18 \\
\hline
\end{tabular}

Standard errors in parentheses.

Bold indicates significant differences between the coefficient onforward and backward linkages at $10 \%$.

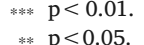

$* \mathrm{p}<0.1$. 
Table 4

The determinants of the domestic to foreign value added content of exports.

\begin{tabular}{|c|c|c|c|c|c|c|c|c|}
\hline & (1) & (2) & (3) & (4) & (5) & (6) & (7) & (8) \\
\hline Variables & \multicolumn{6}{|c|}{ Dependent variable: $\ln ($ dvafex/fvadex $)$} & & \\
\hline lnH_D_totintg & $\begin{array}{l}0.127^{* *} \\
(0.057)\end{array}$ & & & & & & & \\
\hline lnH_D_rd_kstock_k & & $\begin{array}{l}0.085^{* * *} \\
(0.030)\end{array}$ & & $\begin{array}{l}0.086^{*} \\
(0.044)\end{array}$ & & & & \\
\hline lnH_D_intg_xrd_kstock & & & $\begin{array}{l}0.185^{* *} \\
(0.083)\end{array}$ & $\begin{array}{l}-0.004 \\
(0.119)\end{array}$ & & & & \\
\hline lnH_D_train_kstock_k & & & & & $\begin{array}{l}0.268^{* * *} \\
(0.064)\end{array}$ & & & \\
\hline lnH_D_adv_mkt_kstock_k & & & & & & $\begin{array}{l}-0.112 \\
(0.096)\end{array}$ & & \\
\hline lnH_D_arch_des_kstock_k & & & & & & & $\begin{array}{l}-0.158^{* *} \\
(0.071)\end{array}$ & \\
\hline lnH_D_orgcap_kstock_k & & & & & & & & $\begin{array}{l}0.197^{* * *} \\
(0.043)\end{array}$ \\
\hline lnH_D_k_ict & $\begin{array}{l}-0.375^{* * *} \\
(0.067)\end{array}$ & $\begin{array}{l}-0.286^{* * *} \\
(0.044)\end{array}$ & $\begin{array}{l}-0.403^{* * *} \\
(0.074)\end{array}$ & $\begin{array}{l}-0.284^{* * *} \\
(0.074)\end{array}$ & $\begin{array}{l}-0.400^{* * *} \\
(0.063)\end{array}$ & $\begin{array}{l}-0.220^{* *} \\
(0.092)\end{array}$ & $\begin{array}{l}-0.216^{* * z} \\
(0.068)\end{array}$ & $\begin{array}{l}-0.419^{* * *} \\
(0.065)\end{array}$ \\
\hline lnH_D_all_tang_kstock_k & $\begin{array}{l}0.302^{* * *} \\
(0.052)\end{array}$ & $\begin{array}{l}0.273^{* * *} \\
(0.050)\end{array}$ & $\begin{array}{l}0.269^{* * *} \\
(0.058)\end{array}$ & $\begin{array}{l}0.274^{* * *} \\
(0.057)\end{array}$ & $\begin{array}{l}0.123^{*} \\
(0.070)\end{array}$ & $\begin{array}{l}0.361^{* * *} \\
(0.051)\end{array}$ & $\begin{array}{l}0.373^{* * *} \\
(0.047)\end{array}$ & $\begin{array}{l}0.261^{* * *} \\
(0.051)\end{array}$ \\
\hline corporateincometaxrate & $\begin{array}{l}0.002 \\
(0.007)\end{array}$ & $\begin{array}{l}0.001 \\
(0.006)\end{array}$ & $\begin{array}{l}0.001 \\
(0.007)\end{array}$ & $\begin{array}{l}0.001 \\
(0.006)\end{array}$ & $\begin{array}{l}0.002 \\
(0.007)\end{array}$ & $\begin{array}{l}0.005 \\
(0.007)\end{array}$ & $\begin{array}{l}0.004 \\
(0.006)\end{array}$ & $\begin{array}{l}0.001 \\
(0.007)\end{array}$ \\
\hline ln_pop & $\begin{array}{l}0.232^{* * *} \\
(0.030)\end{array}$ & $\begin{array}{l}0.206^{* * *} \\
(0.030)\end{array}$ & $\begin{array}{l}0.217^{* * *} \\
(0.030)\end{array}$ & $\begin{array}{l}0.206^{* * *} \\
(0.030)\end{array}$ & $\begin{array}{l}0.206^{* * *} \\
(0.029)\end{array}$ & $\begin{array}{l}0.232^{* * *} \\
(0.033)\end{array}$ & $\begin{array}{l}0.254^{* * *} \\
(0.034)\end{array}$ & $\begin{array}{l}0.233^{* * *} \\
(0.028)\end{array}$ \\
\hline lneduexp & $\begin{array}{l}0.815^{* * *} \\
(0.207)\end{array}$ & $\begin{array}{l}0.817^{* * *} \\
(0.222)\end{array}$ & $\begin{array}{l}0.744^{* * *} \\
(0.204)\end{array}$ & $\begin{array}{l}0.816^{* * *} \\
(0.224)\end{array}$ & $\begin{array}{l}0.560^{* * * *} \\
(0.208)\end{array}$ & $\begin{array}{l}0.641^{* * *} \\
(0.228)\end{array}$ & $\begin{array}{l}0.657^{* * *} \\
(0.221)\end{array}$ & $\begin{array}{l}0.653^{* * *} \\
(0.183)\end{array}$ \\
\hline $\mathrm{pmr}$ & $\begin{array}{l}-0.575^{* * *} \\
(0.101)\end{array}$ & $\begin{array}{l}-0.536^{* * *} \\
(0.095)\end{array}$ & $\begin{array}{l}-0.532^{* * *} \\
(0.105)\end{array}$ & $\begin{array}{l}-0.538^{* * *} \\
(0.108)\end{array}$ & $\begin{array}{l}-0.378^{* * *} \\
(0.108)\end{array}$ & $\begin{array}{l}-0.674^{* * *} \\
(0.112)\end{array}$ & $\begin{array}{l}-0.682^{* * *} \\
(0.106)\end{array}$ & $\begin{array}{l}-0.456^{* * *} \\
(0.093)\end{array}$ \\
\hline services & $\begin{array}{l}0.305^{* * *} \\
(0.093)\end{array}$ & $\begin{array}{l}0.408^{* * *} \\
(0.083)\end{array}$ & $\begin{array}{l}0.204^{* * *} \\
(0.076)\end{array}$ & $\begin{array}{l}0.410^{* * *} \\
(0.100)\end{array}$ & $\begin{array}{l}0.295^{* * *} \\
(0.081)\end{array}$ & $\begin{array}{l}0.102 \\
(0.105)\end{array}$ & $\begin{array}{l}0.150^{* *} \\
(0.074)\end{array}$ & $\begin{array}{l}0.251^{* * s} \\
(0.073)\end{array}$ \\
\hline 2000.year & $\begin{array}{l}0.219^{* * *} \\
(0.063)\end{array}$ & $\begin{array}{l}0.163^{* * *} \\
(0.058)\end{array}$ & $\begin{array}{l}0.232^{* * *} \\
(0.063)\end{array}$ & $\begin{array}{l}0.162^{* *} \\
(0.065)\end{array}$ & $\begin{array}{l}0.222^{* * *} \\
(0.061)\end{array}$ & $\begin{array}{l}0.183^{* * *} \\
(0.071)\end{array}$ & $\begin{array}{l}0.181^{* * *} \\
(0.068)\end{array}$ & $\begin{array}{l}0.206^{* * s} \\
(0.056)\end{array}$ \\
\hline 2005.year & $\begin{array}{l}0.033 \\
(0.081)\end{array}$ & $\begin{array}{l}-0.077 \\
(0.069)\end{array}$ & $\begin{array}{l}0.083 \\
(0.087)\end{array}$ & $\begin{array}{l}-0.080 \\
(0.096)\end{array}$ & $\begin{array}{l}0.210^{* *} \\
(0.093)\end{array}$ & $\begin{array}{l}-0.045 \\
(0.103)\end{array}$ & $\begin{array}{l}-0.013 \\
(0.088)\end{array}$ & $\begin{array}{l}0.091 \\
(0.076)\end{array}$ \\
\hline 2008.year & $\begin{array}{l}-0.073 \\
(0.098)\end{array}$ & $\begin{array}{l}-0.229^{* * *} \\
(0.085)\end{array}$ & $\begin{array}{l}-0.015 \\
(0.106)\end{array}$ & $\begin{array}{l}-0.232^{* *} \\
(0.116)\end{array}$ & $\begin{array}{l}0.192 \\
(0.118)\end{array}$ & $\begin{array}{l}-0.181 \\
(0.123)\end{array}$ & $\begin{array}{l}-0.130 \\
(0.104)\end{array}$ & $\begin{array}{l}-0.006 \\
(0.095)\end{array}$ \\
\hline 2009.year & $\begin{array}{l}-0.019 \\
(0.100)\end{array}$ & $\begin{array}{l}-0.164^{*} \\
(0.086)\end{array}$ & $\begin{array}{l}0.046 \\
(0.109)\end{array}$ & $\begin{array}{c}-0.167 \\
(0.120)\end{array}$ & $\begin{array}{l}0.252^{* *} \\
(0.120)\end{array}$ & $\begin{array}{l}-0.136 \\
(0.130)\end{array}$ & $\begin{array}{l}-0.075 \\
(0.106)\end{array}$ & $\begin{array}{l}0.060 \\
(0.099)\end{array}$ \\
\hline 2010.year & $\begin{array}{l}0.055 \\
(0.108)\end{array}$ & $\begin{array}{l}-0.090 \\
(0.094)\end{array}$ & $\begin{array}{l}0.129 \\
(0.118)\end{array}$ & $\begin{array}{l}-0.094 \\
(0.129)\end{array}$ & $\begin{array}{l}0.328^{* *} \\
(0.132)\end{array}$ & $\begin{array}{c}-0.064 \\
(0.141)\end{array}$ & $\begin{array}{l}-0.001 \\
(0.117)\end{array}$ & $\begin{array}{l}0.155 \\
(0.106)\end{array}$ \\
\hline Observations & 92 & 82 & 92 & 82 & 92 & 92 & 92 & 92 \\
\hline Number of ctrysec & 18 & 16 & 18 & 16 & 18 & 18 & 18 & 18 \\
\hline
\end{tabular}

Standard errors in parentheses.

**** $\mathrm{p}<0.01$.

** $\mathrm{p}<0.05$.

* $\mathrm{p}<0.1$.

only in manufacturing industries and ICT is relatively more relevant for participation in services. This result supports previous evidence according to which the intangible and information-based nature of services gives to the generation and use of ICT a central role in firms/countries innovation activities and performance (Evangelista, 2000; Guerrieri and Meliciani, 2005).

Third, intangibles foster, even if to a different extent, both forward and backward participation: training and organizational capital are key factors for forward linkages while marketing and advertising and (surprisingly) also design for backward linkages. This evidence only partially supports the role of intangibles along the smiling curve (Mudambi, 2007, 2008; Shin et al., 2009, 2012; Dedrick et al., 2010) and suggests strong complementarities between the use of different intangible assets in the supply chain (Corrado and Hao, 2014).
Finally, knowledge-based capital is positively correlated with value appropriation along the value chain (measured as the domestic value added embodied in foreign exports relative to the foreign value added embodied in domestic exports) and this finding is robust to introducing separately R\&D and non-R\&D intangibles. Among them, in particular training and organizational capital have a large positive effect on value appropriation.

The descriptive evidence reported in the paper also shows the heterogeneous behavior of European countries in terms of both intangible capital accumulation and participation in global value chains. In this respect, the low figures for Mediterranean countries (Italy and Spain) suggest that they may be trapped in a vicious circle of low investment in high value 
added creating activities and low competitiveness in international markets.

Overall, the results of this paper are broadly consistent (and complementary) with the growing literature showing the key role of intangible investment for productivity growth (Corrado et al., 2009, 2013). Further analyses should consider the joint impact of investment in intangibles, participation in GVC and productivity growth.

Finally, due to the short time series, this paper has not tested the possible two-way relationship between investment in intangible assets and participation in GVC. In this respect, further studies with longer time series and more detailed industry data are needed to shed further light on these issues.

\section{Uncited references}

Ackerberg et al., 2015

Appendix 1. Definition of the variables

\begin{tabular}{|c|c|c|}
\hline Name of the variable & Definition & Source \\
\hline lnH_dvafex & $\begin{array}{l}\text { Domestic value added embodied in foreign } \\
\text { exports/hours worked (natural log) }\end{array}$ & Tiva \\
\hline lnH_fvadex & $\begin{array}{l}\text { Foreign value added embodied in domestic } \\
\text { exports/hours worked (natural log) }\end{array}$ & Tiva \\
\hline lnH_dvaffd & $\begin{array}{l}\text { Domestic value added embodied in foreign } \\
\text { final demand/hours worked (natural log) }\end{array}$ & Tiva \\
\hline lnH_fvadfd & $\begin{array}{l}\text { Foreign value added embodied in domestic } \\
\text { final demand/hours worked (natural log) }\end{array}$ & Tiva \\
\hline lnH_D_totintg & $\begin{array}{l}\text { Total intangible capital/hours worked (nat- } \\
\text { ural } \log \text { ) }\end{array}$ & TAN $^{\text {IN- }}$ \\
\hline lnH_D_rd_kstock_k & $\begin{array}{l}\text { R\&D intangible capital/hours worked (nat- } \\
\text { ural } \log \text { ) }\end{array}$ & TAN $^{\text {IN- }}$ \\
\hline $\begin{array}{l}\text { lnH_D_intg_xrd_k- } \\
\text { stock }\end{array}$ & $\begin{array}{l}\text { Intangible capital excluding R\&D/hours } \\
\text { worked (natural log) }\end{array}$ & \\
\hline $\begin{array}{l}\text { lnH_D_train_k- } \\
\text { stock_k }\end{array}$ & $\begin{array}{l}\text { Training intangible capital/hours worked } \\
\text { (natural log) }\end{array}$ & \\
\hline $\begin{array}{l}\text { lnH_D_adv_mkt_k- } \\
\text { stock_k }\end{array}$ & $\begin{array}{l}\text { Brand intangible capital/hours worked } \\
\text { (natural log) }\end{array}$ & \\
\hline $\begin{array}{l}\text { lnH_D_arch_des_k- } \\
\text { stock_k }\end{array}$ & $\begin{array}{l}\text { Architectural design intangible capital/ } \\
\text { hours worked (natural log) }\end{array}$ & \\
\hline $\begin{array}{l}\text { lnH_D_orgcap_k- } \\
\text { stock_k }\end{array}$ & $\begin{array}{l}\text { Organizational intangible capital/hours } \\
\text { worked (natural } \log \text { ) }\end{array}$ & \\
\hline lnH_D_k_ict & ICT capital/hours worked (natural log) & $\begin{array}{l}\text { EU_K- } \\
\text { LEMS }\end{array}$ \\
\hline $\begin{array}{l}\text { lnH_D_all_tang_k- } \\
\text { stock_k }\end{array}$ & $\begin{array}{l}\text { Tangible capital/hours worked (natural } \\
\log )\end{array}$ & $\begin{array}{l}\text { EU_K- } \\
\text { LEMS }\end{array}$ \\
\hline $\begin{array}{l}\text { corporate income } \\
\text { tax rate }\end{array}$ & Corporate income tax rate & OECD \\
\hline $\ln \_$pop & Population (natural $\log$ ) & stat \\
\hline Ineduexp & $\begin{array}{l}\text { Expenditure on education as a share of } \\
\text { GDP (natural log) }\end{array}$ & CANA \\
\hline $\begin{array}{l}\text { pmr } \\
\text { Services }\end{array}$ & Product market regulation indicator & OECD \\
\hline
\end{tabular}

\section{Appendix 2. Robustness checks using lagged regressors}

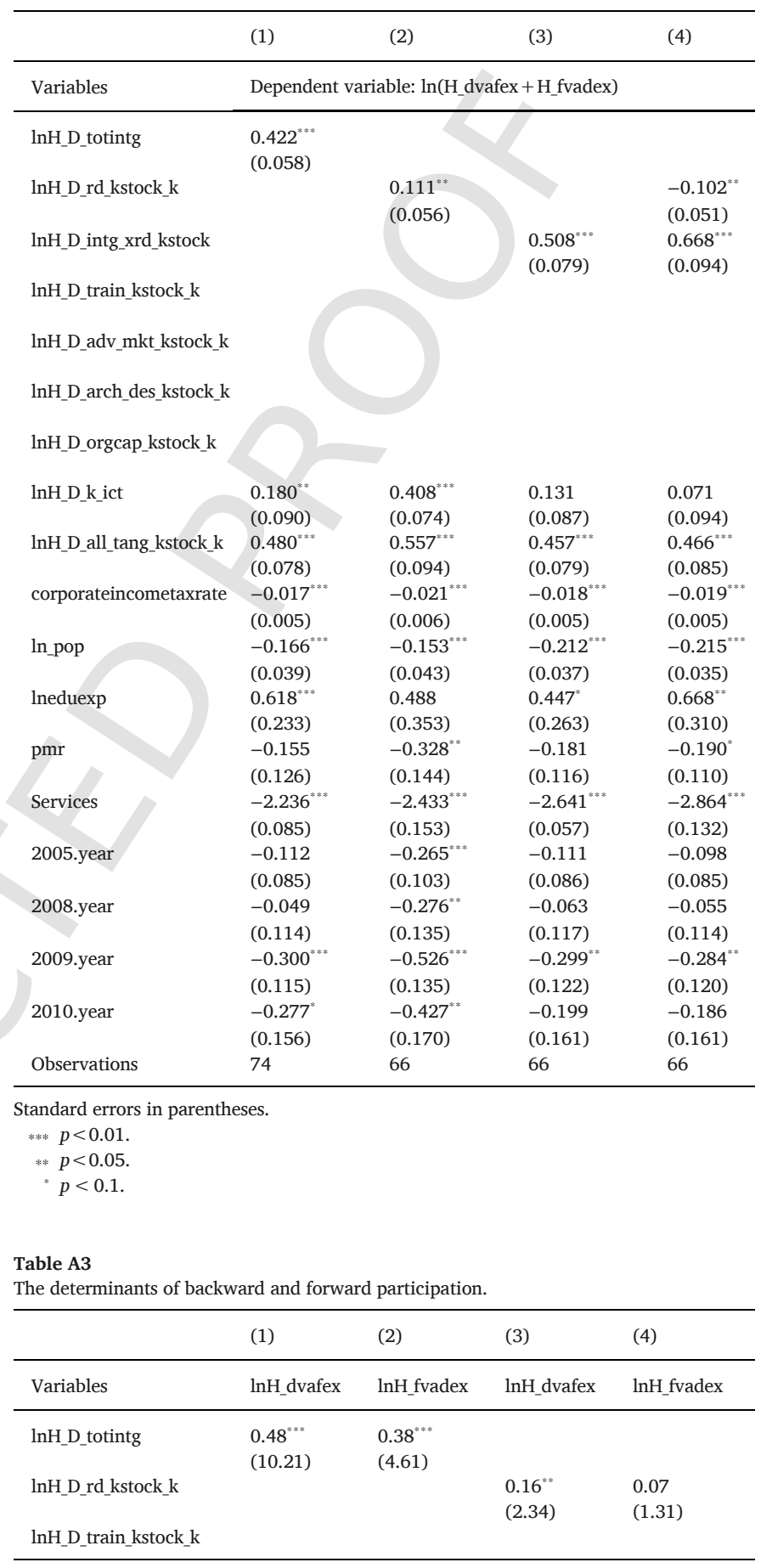

Table A2

The determinants of participation in GVC. 


\begin{tabular}{lllll} 
lnH_D_orgcap_kstock_k & & & & \\
& & & & \\
lnH_D_adv_mkt_kstock_k & & & & \\
& & & & \\
lnH_D_arch_des_kstock_k & & & & \\
& & & & \\
lnH_D_k_ict & -0.04 & $0.36^{* * *}$ & $0.23^{* * *}$ & $0.56^{* * *}$ \\
& $(-0.47)$ & $(2.96)$ & $(3.09)$ & $(6.41)$ \\
lnH_D_all_tang_kstock_k & $0.68^{* * *}$ & $0.31^{* * *}$ & $0.74^{* * *}$ & $0.40^{* * *}$ \\
& $(8.85)$ & $(3.18)$ & $(6.79)$ & $(4.07)$ \\
Corporateincometaxrate & $-0.01^{* * *}$ & $-0.02^{* *}$ & $-0.02^{* * *}$ & $-0.02^{* * *}$ \\
& $(-2.15)$ & $(-2.36)$ & $(-3.02)$ & $(-2.63)$ \\
ln_pop & $-0.08^{*}$ & $-0.26^{* * *}$ & -0.05 & $-0.25^{* * *}$ \\
& $(-1.85)$ & $(-5.27)$ & $(-1.01)$ & $(-5.18)$ \\
lneduexp & $0.60^{* * *}$ & 0.51 & $0.88^{* *}$ & 0.14 \\
& $(3.33)$ & $(1.43)$ & $(2.03)$ & $(0.39)$ \\
pmr & $-0.62^{* * *}$ & $0.27^{*}$ & $-0.76^{* * *}$ & 0.09 \\
& $(-4.50)$ & $(1.70)$ & $(-4.22)$ & $(0.64)$ \\
Observations & 74 & 74 & 66 & 66 \\
R-squared & 0.97 & 0.94 & 0.96 & 0.96 \\
\hline
\end{tabular}

Robust z-statistics in parentheses.

**** $\mathrm{p}<0.01$.

**: $\mathrm{p}<0.05$.

. $\mathrm{p}<0.1$.

\section{Appendix 3. Robustness checks using GVC indicators based on final demand}

Table A4

The determinants of participation in GVC.

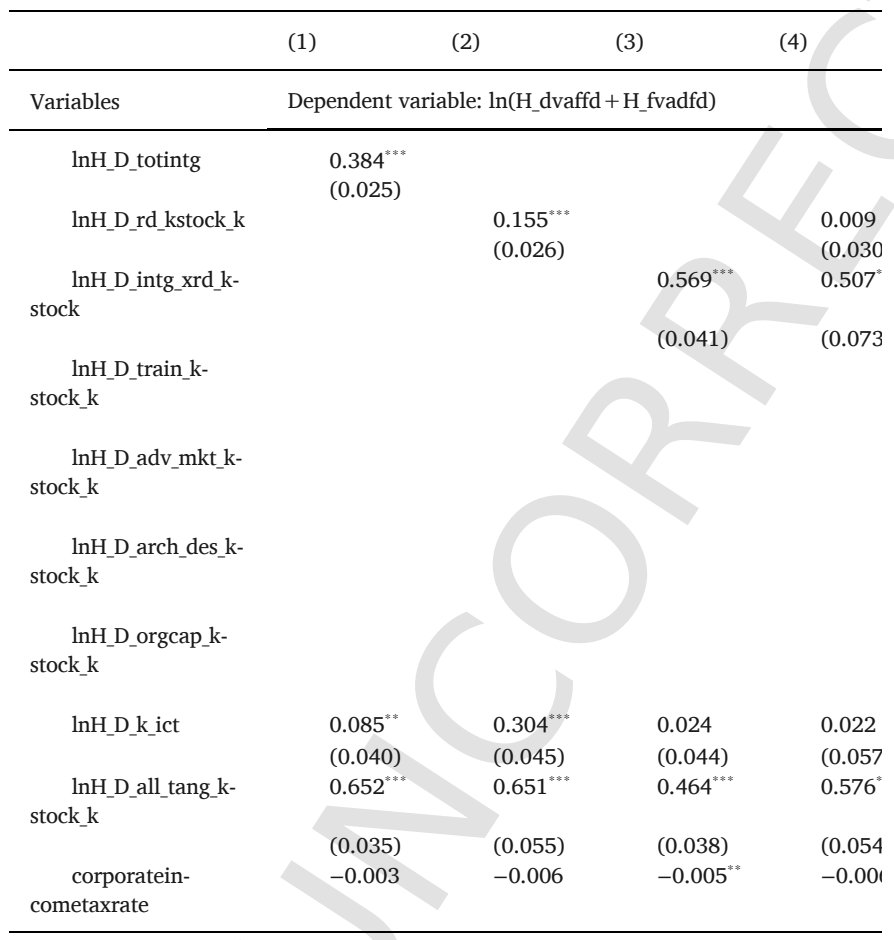

\begin{tabular}{lllll}
\hline \multirow{4}{*}{ ln_pop } & $(0.002)$ & $(0.004)$ & $(0.002)$ & $(0.002)$ \\
& $-0.076^{* * *}$ & $-0.067^{* * *}$ & $-0.093^{* * *}$ & $-0.106^{* * *}$ \\
lneduexp & $(0.023)$ & $(0.023)$ & $(0.025)$ & $(0.025)$ \\
& 0.011 & -0.031 & -0.130 & 0.046 \\
pmr & $(0.092)$ & $(0.173)$ & $(0.079)$ & $(0.144)$ \\
Services & $-0.184^{* * *}$ & $-0.322^{* * *}$ & 0.055 & -0.040 \\
& $(0.061)$ & $(0.097)$ & $(0.073)$ & $(0.095)$ \\
2000.year & $-0.872^{* * *}$ & $-0.869^{* * *}$ & $-1.066^{* * *}$ & $-1.109^{* * *}$ \\
& $(0.041)$ & $(0.081)$ & $(0.035)$ & $(0.068)$ \\
2005.year & $0.154^{* * *}$ & 0.067 & $0.168^{* * *}$ & $0.202^{* * *}$ \\
& $(0.035)$ & $(0.047)$ & $(0.035)$ & $(0.042)$ \\
2008.year & 0.060 & $-0.202^{* * *}$ & $0.211^{* * *}$ & $0.159^{* * *}$ \\
& $(0.048)$ & $(0.063)$ & $(0.055)$ & $(0.072)$ \\
2009.year & 0.043 & $-0.282^{* * *}$ & $0.269^{* * *}$ & $0.172^{*}$ \\
& $(0.060)$ & $(0.082)$ & $(0.072)$ & $(0.097)$ \\
2010.year & -0.087 & $-0.424^{* * *}$ & $0.156^{* *}$ & 0.047 \\
& $(0.060)$ & $(0.082)$ & $(0.073)$ & $(0.099)$ \\
Observations & -0.058 & $-0.395^{* * *}$ & $0.186^{*}$ & 0.089 \\
Number of ctrysec & $(0.105)$ & $(0.105)$ & $(0.112)$ & $(0.127)$ \\
& 92 & 82 & 92 & 82 \\
\hline
\end{tabular}

Standard errors in parentheses.

*** $\mathrm{p}<0.01$.

** $\mathrm{p}<0.05$

${ }^{*} \mathrm{p}<0.1$.

Table A5

The determinants of backward and forward participation.

\begin{tabular}{|c|c|c|c|c|}
\hline & (1) & (2) & (3) & (4) \\
\hline Variables & (lnH_dvaffd) & (lnH_fvadfd) & (lnH_dvaffd) & (lnH_fvadf \\
\hline lnH_D_totintg & $\begin{array}{l}0.465^{* * *} \\
(0.037)\end{array}$ & $\begin{array}{l}0.312^{* * *} \\
(0.052)\end{array}$ & & \\
\hline lnH_D_rd_kstock_k & & & $\begin{array}{l}0.236^{* * *} \\
(0.036)\end{array}$ & $\begin{array}{l}0.076^{*} \\
(0.042)\end{array}$ \\
\hline \multicolumn{5}{|l|}{ lnH_D_train_kstock_k } \\
\hline \multicolumn{5}{|l|}{ lnH_D_adv_mkt_kstock_k } \\
\hline \multicolumn{5}{|l|}{ lnH_D_arch_des_kstock_k } \\
\hline \multicolumn{5}{|l|}{ lnH_D_orgcap_kstock_k } \\
\hline lnH_D_k_ict & $\begin{array}{l}0.089^{*} \\
(0.052)\end{array}$ & $\begin{array}{l}-0.029 \\
(0.073)\end{array}$ & $\begin{array}{l}0.332^{* * *} \\
(0.060)\end{array}$ & $\begin{array}{l}0.147^{* *} \\
(0.070)\end{array}$ \\
\hline lnH_D_all_tang_kstock_k & $\begin{array}{l}0.527^{* * *} \\
(0.048)\end{array}$ & $\begin{array}{l}0.790^{* * *} \\
(0.067)\end{array}$ & $\begin{array}{l}0.463^{* * *} \\
(0.075)\end{array}$ & $\begin{array}{l}0.894^{* * *} \\
(0.087)\end{array}$ \\
\hline corporateincometaxrate & $\begin{array}{l}-0.018^{* * *} \\
(0.004)\end{array}$ & $\begin{array}{l}0.007 \\
(0.006)\end{array}$ & $\begin{array}{l}-0.018^{* * *} \\
(0.006)\end{array}$ & $\begin{array}{l}0.004 \\
(0.007)\end{array}$ \\
\hline ln_pop & $\begin{array}{l}-0.088^{* * *} \\
(0.025)\end{array}$ & $\begin{array}{l}0.050 \\
(0.035)\end{array}$ & $\begin{array}{l}-0.105^{* * *} \\
(0.034)\end{array}$ & $\begin{array}{l}0.069^{*} \\
(0.039)\end{array}$ \\
\hline lneduexp & $\begin{array}{l}0.137 \\
(0.122)\end{array}$ & $\begin{array}{l}0.274 \\
(0.173)\end{array}$ & $\begin{array}{l}-0.352 \\
(0.275)\end{array}$ & $\begin{array}{l}0.709^{* *} \\
(0.321)\end{array}$ \\
\hline $\mathrm{pmr}$ & $\begin{array}{l}-0.012 \\
(0.074)\end{array}$ & $\begin{array}{l}-0.448^{* * *} \\
(0.105)\end{array}$ & $\begin{array}{l}-0.021 \\
(0.105)\end{array}$ & $\begin{array}{l}-0.590^{* * *} \\
(0.122)\end{array}$ \\
\hline services & $\begin{array}{l}-0.353^{* * *} \\
(0.049)\end{array}$ & $\begin{array}{l}-1.282^{* * *} \\
(0.070)\end{array}$ & $\begin{array}{l}-0.169 \\
(0.110)\end{array}$ & $\begin{array}{l}-1.423^{* * *} \\
(0.129)\end{array}$ \\
\hline
\end{tabular}




\begin{tabular}{lllll}
\hline 2000.year & $0.111^{* *}$ & $0.223^{* * *}$ & -0.052 & $0.197^{* *}$ \\
2005.year & $(0.055)$ & $(0.077)$ & $(0.075)$ & $(0.087)$ \\
& 0.006 & 0.098 & $-0.201^{* *}$ & -0.100 \\
2008.year & $(0.062)$ & $(0.088)$ & $(0.082)$ & $(0.096)$ \\
& -0.022 & 0.109 & $-0.235^{* *}$ & -0.172 \\
2009.year & $(0.073)$ & $(0.103)$ & $(0.101)$ & $(0.118)$ \\
& $-0.136^{*}$ & -0.007 & $-0.364^{* * *}$ & $-0.290^{* *}$ \\
2010.year & $(0.073)$ & $(0.104)$ & $(0.101)$ & $(0.118)$ \\
& -0.133 & 0.179 & $-0.391^{* *}$ & -0.091 \\
Observations & $(0.120)$ & $(0.170)$ & $(0.158)$ & $(0.185)$ \\
Number of ctrysec & 92 & 92 & 82 & 82 \\
\hline
\end{tabular}

Standard errors in parentheses.

**** $\mathrm{p}<0.01$.

*** $\mathrm{p}<0.05$.

${ }^{*} \mathrm{p}<0.1$.

\section{References}

Ackerberg, D.A., Caves, K., Frazer, G., 2015. Identification properties of recent production function estimators. Econometrica 83, 2411-2451.

Augier, M., Teece, D.J., 2006. Understanding complex organization: the role of know-how, internal structure and human behavior in the evolution of capabilities. Ind. Corp. Chang. 15 (2), 395-416.

Baldwin, R., 2011. Trade and industrialization after globalization's 2nd unbundling: how building and joining a supply chain are different and why it matters. NBER Working Paper n. 17716.

Baldwin, R., et al., 2012. Global supply chains: Why they emerged, why they matter, and where they are going. CEPR Discussion Papers 9103, C.E.P.R. Discussion Papers.

Baldwin, R., López-Gonzalez, J., 2015. Supply-chain trade: a portrait of global patterns and several testable hypotheses. World Econ. 38, 1682-1721.

Banga, Banga, R. (2013), 'Measuring value in global value chains', Background 2013 paper n. RVC-8, UNCTAD.

Bloom, R., Van Reenen, J., 2007. Measuring and explaining management practices across firms and countries. Q. J. Econ. 122, 1351-1408.

Bloom, R., Sadun, R., Van Reenen, J., 2016. Management as a technology. NBER Workin Paper n. 22327.

Castellacci, F., Natera, J.M., 2011. A new panel dataset for cross-country analyses of national systems, growth and development (CANA). Innovation and Development 1, 205-226.

Chen, W., Los, B., Timmer, M., et al., 2018. Factor Incomes in Global Value Chains: The Role of Intangibles. National Bureau of Economic Research, Inc. Working Papers Working Papers 25242.

Cheng, K., Rehmen, S., Seneviratne, D., Zhang, S., 2015. Reaping the benefits from global value chains. IMF Working Paper 15 (204).

Cohen, W.M., 2010. Fifty years of empirical studies of innovative activity and performance. In: Hall, B.H., Rosenberg, N. (Eds.), Handbook of the Economics of Innovation, 129-213, North-Holland, Elsevier, Amsterdam.

Corrado, C., Hao, J.X., 2014. Brands as productive assets: concepts, measurement and global trends. WIPO Economic Research Working Paper 14

Corrado, C., Hulten, C., Sichel, D., 2005. Measuring capital and technology: An expanded framework. In: Corrado, C., Haltiwanger, J., Sichel, D. (Eds.), Measuring Capital in the New Economy, National Bureau of Economic Research Studies in Income and Wealth, 11-45, The University Chicago Press, Chicago.

Corrado, C.A., Sichel, D.E., Hulten, C.R., 2009. Intangible capital and U.S. economic growth. Rev. Income Wealth 85, 661-685.
Corrado, C., Haskel, J., Jona-Lasinio, C., Iommi, M., 2013. Innovation and intangible investment in Europe, Japan and the United States. Oxf. Rev. Econ. Policy 29, 261-286.

Corrado, C., Haskel, J., Jona-Lasinio, C., Iommi, M., 2016. 'Intangible Investment in the EU and the US before and since the Great Recession and its Contribution to Productivity growth', EIB Working Papers 2016/08, European Investment Bank, Luxemburg.

Corrado, C., Haskel, J., Jona-Lasinio, C., 2017. Knowledge spillovers, ICT and productivity growth. Oxford Bullettin of Economics and Statistics 79, 0305-9049.

De Backer, K., Miroudot, S., 2013. Mapping global value chains. OECD Trade Policy Papers $159,1-46$.

Dedrick, J., Kramer, K.L., Linden, G., 2010. Who profits from innovation in global value chain? A study of the iPod and notebook PCs. Ind. Corp. Chang. 19, 81-116.

Dosi, G., Freeman, C., Nelson, R., Silverberg, G., Soete, L. (Eds.), 1988. Technical Change and Economic Theory, Pinter Publisher, London.

Dosi, G., Pavitt, K., Soete, L., 1990. The Economics of Technical Change and International Trade, New York University Press, New York.

Dosi, G., Grazzi, M., Moschella, D., 2015. Technology and costs in international competitiveness: from countries and sectors to firms. Res. Policy 44, 1795-1814.

Draca, M., Sadun, R., Van Reenen, J., 2006. Productivity and ICT: A Review of the Evidence', CEP Discussion Paper n. 749, Centre for Economic Performance, London School of Economics.

Durand, Miller, et al., 2018. Intellectual Monopoly in Global Value Chains. Working Papers 1807, New School for Social Research, Department of Economics.

Evangelista, R., 2000. Sectoral patterns of technological change in services. Econ. Innov. New Technol. 9, 183-221.

Everatt, D., Tsai, T., Chang, B., 1999. 'The acer group's China manufacturing decision. In: Richard Ivey School of Business Case Series \#9A99M009, University of Western, Ontario.

Fagerberg, J., 1994. Technology and international differences in growth rates. J. Econ. Lit. $32,1147-1175$.

Fukao, K., Miyagawa, T., Mukai, K., Shinoda, Y., Tonogi, K., 2009. Intangible investment in Japan: measurement and contribution to economic growth. Rev. Income Wealth 55 , 717-736.

Gereffi, G., Fernandez-Stark, K., 2010. The offshore services value chains. Developing countries and the crisis. The World Bank Policy Research Working Papers 5262

Gereffi, G., Humphrey, J., Sturgeon, T., 2005. The governance of global value chains. Rev. Int. Polit. Econ. 12, 78-104.

Grant, R.M., 1996. Towards a knowledge-based theory of the firm. Strateg. Manag. J. 17, 109-122.

Guerrieri, P., Meliciani, V., 2005. Technology and international competitiveness: the interdependence between manufacturing and producer services. Struct. Chang. Econ. Dyn. $16,489-502$.

Hao, J.X., Manole, V., van Ark, B., 2008. Intangible capital and economic growth - an international comparison. In: Economics Program Working Paper Series.

Haskel, J., Lawrence, R.Z., Leamer, E.E., Slaughter, M., 2012. Globalization and US wages: modifying classical theory to explain recent facts. J. Econ. Perspect. 26 (2), 119-140.

Hummels, D., Ishii, J., Kei-Mu, Y., 2001. The nature and growth of vertical specialisation in world trade. J. Int. Econ. 54, 75-96.

Jalava Jalava, J., A. Pirkko and A. Aku (2007), 'Intangible Capital in the et al., $\quad$ Finnish Business Sector 1975-2005', Discussion Papers n. 1103, The 2007 Research Institute of the Finnish Economy.

Hummels, D., Schaur, G., et al., 2013. Time as a Trade Barrier. American Economic Review 103(7) (December), 2935-2959.

Johnson, R.C., Noguera, G., 2012. Accounting for intermediates: productions sharing and trade in value added. J. Int. Econ. 86, 224-236.

Kaplinsky, R., 2000. Globalisation and unequalisation: what can be learned from value chain analysis? J. Dev. Stud. 37, 117-146.

Kaplinsky, R., 2016. Global value chain, where they came from, where they are going and why this is important. In: Weisse, J., Tribe, M. (Eds.), Rout- 
ledge Handbook of Industry and Development, 184-204, Routledge, London and New York.

Kogut, B., Zander, U., 1993. Knowledge of the firm and the evolutionary theory of the multinational corporation. J. Int. Bus. Stud. 24 (4), 625-645.

Kommerskollegium, 2012. Everybody in services - the impact of servicification in manufacturing on trade and trade policy. In: Swedish National Board of Trade.

Koopman, R., Powers, W., Wang, Z., Wei, S.-J., 2010. Give credit where credit is due: tracing value added in global production chains. NBER Working Paper n. 16426.

Koopman, R., Wang, Z., Wei, S.-J., 2014. Tracing value-added and double counting in gross exports. Am. Econ. Rev. 104, 459-494.

Koske, I., Wanner, I., Bitetti, R., Barbiero, O., 2015. The 2013 update of the OECD product market regulation indicators: policy insights for OECD and non-OECD countries. OECD Economics Department Working Papers n. 1200.

Kowalski, P., Gonzalez, J.L., Ragoussis, A., Ugarte, C., 2015. 'Participation of developing countries in global value chains: implications for trade and trade-related Policies', OECD trade policy papers n. 179, OECD publishing. Paris.

Lanz, R., Maurer, A., 2015. Services and global value chains: servicification of manufacturing and services networks. Journal of International Commerce, Economics and Policy 6, 1-18.

Laursen, K., Meliciani, V., 2010. The role of ICT knowledge flows for international market share dynamics. Res. Policy 39, 687-697.

Lev, B., 2001. Intangibles: Management, Measurement and Reporting, Brookings Institution Press, Washington, DC.

López-Gonzalez, J., Meliciani, V., Savona, M., 2015. When Linder meets Hirschman. Inter-industry linkages and GVCs in services. SPRU Working Paper Series SWPS 2015-20.

Los, B., Timmer, M.P., de Vries, G.J., 2015. How global are global value chains? A new approach to measure international fragmentation. J. Reg. Sci. 55, 66-92.

Lund Vinding, A., 2006. Absorptive capacity and innovative performance: a human capital approach. Econ. Innov. New Technol. 15, 507-517.

Maggi, B., 2017. A technology-based countries-interaction dynamic model for the study of European growth and stability: were there the conditions for convergence? Technol. Forecast. Soc. Chang. 125, 275-288.

Marcolin, L., Le Mouel, M., Squicciarini, M., 2017. 'Investment in Knowledge-Based Capital and Backward Linkages in Global Value Chains', OECD Science, Technology and Industry Working Papers, OECD Publishing. Paris. forthcoming.

Marrano, M.G., Haskel, J., Wallis, G., 2009. What happened to the knowledge economy? ICT, intangible investment and Britain's productivity record revisited. Rev. Income Wealth 55, 686-716.

Marrocu, E., Paci, R., Pontis, M., 2012. Intangible capital and firms' productivity. Ind. Corp. Chang. 21, 377-402.

McCann, P., Mudambi, R., 2005. Analytical differences in the economics of geography: the case of the multinational firm. Environ Plan A 37 (10), 1857-1876.

Miroudot, S., Cadestin, C., 2017. 'Services In Global Value Chains: From Inputs to Value Creating Activities' OECD Trade Policy Papers 197, Publishing, OECD.

Mudambi, R., 2007. Offshoring: economic geography and the multinational firm. J. Int. Bus. Stud. 38, 206.

Mudambi, R., 2008. Location, control and innovation in knowledge-intensive industries. J. Econ. Geogr. 8, 699-725.

Niebel, T., O'Mahony, M., 2017. The contribution of intangible assets to the sectoral productivity growth in the EU. Rev. Income Wealth 63, S49-S67.

OECD, 2013. 'Knowledge-based Capital and Upgrading in Global Value chains', in Supporting Investment in Knowledge Capital, OECD Publishing, Paris, Growth and Innovation.

OECD, 2013. Interconnected Economies. Benefiting from Global Value Chains, OECD Publishing, Paris.

O'Mahony, M., 2012. Human capital formation and continuous training: evidence for EU countries. The Review of Income and Wealth 58, 531-549.
O'Mahony, M., Timmer, M., 2009. Output, input and productivity measures at the industry level: the EU KLEMS database. Economic Journal 119, F374-F403.

Rungi, A., Del Prete, D., 2017. The 'smile curve': where value is added along supply chains. In: Working Papers 05/2017, IMT Institute for Advanced Studies Lucca.

Schiller, S., Perera, H., 2012. Importance of managing intangible assets in enhancing dynamic capabilities of firms: cases from Sweden and Germany. Annals of Innovation and Entrepreneurship 3, 17292.

Schmitz, H., Strambach, S., 2009. The organisational decomposition of innovation and global distribution of innovative activities: insights and research agenda. International Journal of Technological Learning, Innovation and Development 2, 231-249.

Schricke, E., Zenker, A., Stahlecher, T., 2012. 'Knowledge-intensive (Business) Services in Europe', European Commission, Directorate-General for Research and Innovation, Brussels.

Shin, N., Kraemer, K.L., Dedrick, J., 2009. R\&D, value chain location and firm performance in the global electronics industry. Ind. Innov. 16, 315-330.

Shin, N., Kraemer, K.L., Dedrick, J., 2012. Value capture in the global electronics industry: empirical evidence for the 'smiling curve' concept. Ind. Innov. 19, 89-107.

Thum-Thysen, A., Voigt, P., Bilbao-Osorio, B., Maier, C., Ognyanova, D., 2017. 'Unlocking Investment in Intangible Assets', Discussion Paper 047, Commission, European.

Timmer Timmer, Marcel P., Bart Los, Robert Stehrer, and Gaaitzen J. de et al., Vries. (2013), 'Fragmentation, Incomes and Jobs. An Analysis of $2013 \quad$ European Competitiveness'. Economic Policy 28, 613-61.

Timmer, M., Los, B., Stehrer, R., de Vries, G., 2014. Slicing up global value chains. J. Econ. Perspect. 28, 99-118.

Tomlinson, M., 2000. Information and technology flows from the service sector: A UK-Japan comparison. In: Boden, M., Miles, I. (Eds.), Services and the Knowledge-based Economy, Continuum, London.

United Na-

tions Statisti-

cal Division,

$$
2018
$$

United Nations Statistical Division (2018), Handbook on Accounting for Global Value Chains (UNDS),https://unstats.un.org/ unsd/trade/events/2018/rome/ default.asp

World Trade Organization, 2014. The Rise of Global Value Chains, World Trade Report, Geneva.

\section{Biography}

Cecilia Jona-Lasinio is Senior Researcher at the Econometric Studies and Economic Forecasting Division at the Italian Statistical Institute (Istat) and Adjunct Professor of International economics at LUISS Guido Carli, University in Rome. She authored many publications in the area of ICT, Intangibles and Productivity Growth. She has worked on several EU funded research projects and consultancies for government agencies and international organizations. Her main research interests are productivity growth, knowledge based capital and ICT and macro-econometric modelling and forecasting. She received her Ph.D in Econometrics and Empirical Economics at the University of Tor Vergata, Rome, Italy, and the Master degree in International Economics, DES (Diplome d'Etudes Superieures en Relationes Internationales), at the Graduate Institute of International Studies, Geneva, (Switzerland).

Stefano Manzocchi is Professor of International Economics and Dean of the Department of Economics and Finance at LUISS University in Rome. He holds a BA in Economics from the University of Rome "La Sapienza", and a PhD in Economics from the Graduate Institute of International Studies of the University of Geneva. He has published on capital movements and FDI, economic growth and trade issues. Currently he is also Associate Research Fellow of the Centre for European Policy Studies in Brussels. 
Valentina Meliciani is Professor of Applied Economics at the LUISS Guido Carli University of Rome, Italy. She has a PhD from SPRU (Sussex University), a Doctorate from the University of Rome "Tor Vergata", a Master in Interna- tional Economics from the University of Sussex. She has been visiting Fellow at SPRU (Sussex University), Visiting Scholar at the University of Minnesota and Visiting Professor at the London School of Economics and Political Science. Her research focuses on the impact of technology on international competitiveness and economic growth. 